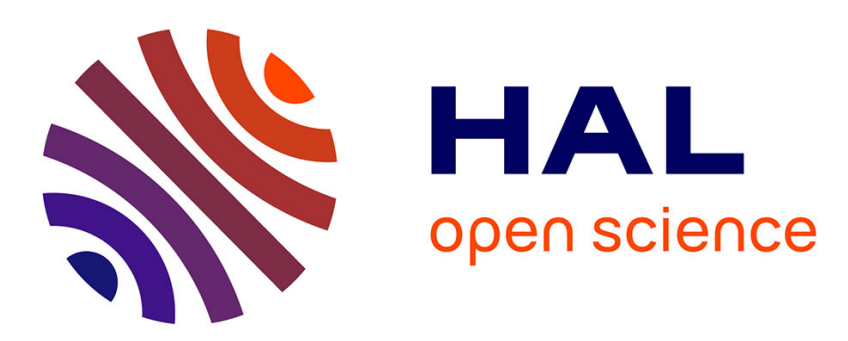

\title{
Mesozoic Extensional Tectonics in Eastern Asia: The South Liaodong Peninsula Metamorphic Core Complex (NE China)
}

Wei Lin, Michel Faure, Patrick Monié, Urs Schärer, Dominique Panis

\section{- To cite this version:}

Wei Lin, Michel Faure, Patrick Monié, Urs Schärer, Dominique Panis. Mesozoic Extensional Tectonics in Eastern Asia: The South Liaodong Peninsula Metamorphic Core Complex (NE China). Journal of Geology, 2008, 116, pp.134-154. 10.1086/527456 . insu-00362879

HAL Id: insu-00362879

https://hal-insu.archives-ouvertes.fr/insu-00362879

Submitted on 14 Aug 2009

HAL is a multi-disciplinary open access archive for the deposit and dissemination of scientific research documents, whether they are published or not. The documents may come from teaching and research institutions in France or abroad, or from public or private research centers.
L'archive ouverte pluridisciplinaire $\mathbf{H A L}$, est destinée au dépôt et à la diffusion de documents scientifiques de niveau recherche, publiés ou non, émanant des établissements d'enseignement et de recherche français ou étrangers, des laboratoires publics ou privés. 


\title{
Mesozoic Extensional Tectonics in Eastern Asia: The South Liaodong Peninsula Metamorphic Core Complex (NE China)
}

\author{
Wei Lin, Michel Faure, ${ }_{1}$ Patrick Monie', 2 Urs Scha rer, ${ }_{3}$ and Dominique Panis 1 \\ 1 Institut des Sciences de la Terre d'Orléans, Centre National de la Recherche Scientifique (CNRS) Unité Mixte de Recherche \\ (UMR) 6113, Bâtiment Géosciences, Université d'Orléans, F-45067 Orléans Cedex 2, France. \\ 2 Laboratoire de Dynamique de la Lithosphè re, CNRS UMR 5573, Universite' Montpellier 2 Place E.-Bataillon, F-34095 \\ Montpellier Cedex, France. \\ ${ }_{3}$ Géochronologie, Géosciences Azur CNRS UMR 6526, Université Nice-Sophia Antipolis, parc Valrose, F-06108 Nice, \\ France.
}

\begin{abstract}
In the North China block, the south Liaodong Peninsula massif is an elliptical metamorphic core complex (MCC) with a long axis trending NE-SW. In cross-section view, it is asymmetric, with a steeply dipping northwestern flank and a gently dipping southeastern flank. It consists of three lithotectonic units: a gneissic migmatite unit, a Paleoto Meso-Proterozoic micaschist-slate unit, and a Neoproterozoic to Mesozoic sedimentary cover. Three deformation events related to extensional tectonics are distinguished in the study area: D1 is a ductile deformation related to the exhumation of the MCC; the following event, D2, corresponds to the development of recumbent folds formed during the early exhumation of the MCC; and the youngest event, D3, corresponds to brittle normal faulting that controlled the opening of a Cretaceous continental half-graben basin. A pre-D1 event characterized as northward verging is interpreted as the result of N-S shortening that occurred in the Late Triassic during the final stages of the collision between the North and South China blocks. The ductile and brittle structures were developed coevally, with synkinematic plutonism and formation of half-grabens. New 40Ar/39Ar and $\mathrm{U} / \mathrm{Pb}$ Cretaceous ages obtained from the mylonitic granodiorite, gneissic migmatite, orthogneiss, and granite indicate that the south Liaodong PeninsulaMCC is contemporaneous with other Cretaceous extensional structures, such as numerous syntectonic plutons bounded by ductile normal faults, MCC, and half-graben basins, described in eastern China. Among the several hypotheses proposed to account for the Mesozoic extension along the eastern margin of Eurasia, lithosphere convective removal appears to be the most likely.
\end{abstract}

\section{Introduction}

Following its Neo-Archean to Proterozoic evolution, the North China block (NCB) experienced a complex tectonic evolution during Late Paleozoic-Mesozoic times (Yin and Nie 1993, 1996; Kusky and Li 2003). The Qinling-Dabie-Sulu Belt is the boundary between the NCB and the South China block (SCB) where ultrahighpressure metamorphic rocks attest for deep continental subduction (fig. 1; Mattauer et al. 1985; Yin and Nie 1993; Ratschbacher et al. 2003). The northern boundary of the NCB corresponds to the collision zone between the NCB and the Paleozoic Mongolian arcs during Late Permian to Early Triassic times ( $\mathrm{S}$, engo" $r$ and Natal'in 1996; Xiao et al. 2003; Shang 2004). These two collisional events, which occurred along the north and south margin of the NCB, were followed first by a Late Jurassic intracontinental compression and second by a widespread extension (Darby et al. 2001; Davis et al. 2001; Zhai et al. 2004). On the basis of geophysical data and petrological studies of mantle xenoliths recovered from Mesozoic to Cenozoic basalts, the current lithosphere thickness ranges from 70 to $120 \mathrm{~km}$ (Fan and Menzies 1992; Menzies et al. 1993; Zhang 2005). The Late Mesozoic extension was coeval with an important Jurassic-Cretaceous magmatism that extends for more than $4000 \mathrm{~km}$ along strike, from the Okhotsk Sea to Vietnam (Zorin 1999; Ren et al. 2002; Wu et al. 2005a). In eastern China, rift-related basins (mostly expressed by the halfgraben basins) and associated metamorphic complexes were recognized for a long time, even before the development of plate tectonics (Huang 1945). Several geodynamic models have been proposed to explain them (Watson et al. 1987; 
Traynor and Sladen 1995; Yin and Nie 1996; Ratschbacher et al. 2000; Ren et al. 2002; Meng et al. 2003; Wu et al. 2005a), but in spite of earlier structural works (Davis et al. 1996, 2002; Darby et al. 2004; Liu et al. 2005; Lin and Wang 2006), the relationships between crustal extension, magmatism, and lithospheric thinning are not well understood. This study focuses on structural and geochronological investigations related to extensional tectonics in the south Liaodong Peninsula in NE China. Our results show that the south Liaodong Peninsula massif is a Cretaceous metamorphic core complex (MCC) that developed after the Late Triassic NCB-SCB final shortening. The south Liaodong Peninsula massif allow us to examine in a small area two types of extensional structures formed coevally: a synmetamorphic and plutonic ductile shear zone in depth and synkinematic half-grabens at the surface. The significance of this MCC is discussed in the tectonic frame of the Mesozoic crustal and lithospheric thinning of eastern China.

\section{Geological Overview of the South Liaodong Peninsula Massif}

In the southern part of the Liaoning Province and to the east of the Tan-Lu fault, the south Liaodong Peninsula massif (fig. 2) consists of three lithotectonic units, which are, from bottom to top, (1) foliated migmatites and amphibolites of Archean and Paleoproterozoic ages, considered to represent basement rocks of the south Liaodong Peninsula massif (LBGMR 1989; Yin and Nie 1996; Faure et al. 2004; Lu et al. 2004), (2) Paleo- to Meso-Proterozoic micaschists and slates of the so-called Gaixian group (LBGMR 1989), and (3) Neoproterozoic to Mesozoic sedimentary rocks. These three units are intruded by several generations of Mesozoic plutons. Although detailed chemical analyses and thermobarometric data concerning the metamorphic assemblages are lacking, the omnipresence of biotite-garnetorthopyroxene assemblages in the gneiss indicates that metamorphism in the south Liaodong Peninsula massif occurred under an intermediate $P T$ regime. Most of the sedimentary rocks belong to Neoproterozoic and Paleozoic series (LBGMR 1989; fig. 2). In the western and southeastern parts of the massif, Neoproterozoic and Paleozoic rocks consist of carbonates, sandstones, quartzites, and slates. As in other parts of the NCB, Late Ordovician to Middle Carboniferous series are lacking. As shown by the pervasive occurrence of chlorite and sericite in phyllite and quartzite, these rocks experienced a greenschist facies metamorphism.

In the northern part of the massif, Paleozoic and late Neoproterozoic rocks are missing, and lower Neoproterozoic sedimentary rocks directly overlie metamorphic rocks. Mesozoic granitoids plutons are widespread in the northern part of the massif, but they are also exposed in the center of the migmatitic massif. Normal faults are located mainly along the western boundary of the massif, where they separate the sedimentary cover from the metamorphic complex. In the study area, Late Jurassic to Cretaceous continental red beds crop out in half-grabens surrounding the south Liaodong Peninsula massif (fig. 2). Their structure is described in "Bulk Architecture of the South Liaodong Peninsula Massif." On the basis of petrological and geochronological studies, two groups of plutonic rocks can be distinguished in the study area. First, biotite-bearing granites and subordinate monzogranites show ages ranging from 110 to $135 \mathrm{Ma}$, that is, the Lower Cretaceous (Guo et al. 2004; Wu et al. 2005b; see "Geochronological Constraints"). These plutons are generally not foliated, but in the vicinity of ductile normal faults, they exhibit well-marked planar and linear fabrics outlined by mineral-preferred orientations. Previous works argue that the monzogranites are syntectonic plutons (Guo et al. 2004; Liu et al. 2005). Second, 
more rarely exposed biotite-hornblende granodiorites and tonalites yield Middle Jurassic ages ranging from 150 to $180 \mathrm{Ma}$ (Wu et al. 2005b; see "Geochronological Constraints"). As described below, these granitoids show a well-developed postsolidus foliation and stretching lineation, with abundant microgranular mafic enclaves composed of K-feldspar, quartz, biotite, amphibole, epidote, garnet, pyrite, and titanite. Epidote formed around allanite or chlorite corroborates the occurrence of a greenschist facies metamorphic overprint on primary magmatic minerals (Chen et al. 1999). In the northern part of the study area, the Yimawanshan porphyritic monzogranitic massif (fig. 2) has been considered syntectonic pluton emplaced during the regional extension (Guo et al. 2004; Liu et al. 2005). In addition to these two types of plutonic rocks, numerous pegmatite, aplite, and diabase dykes crosscut the foliated migmatites as well as the lower part of the cover series (fig. 2). In the south Liaodong Peninsula massif, deformation features were considered by previous workers to have been formed in a variety of different tectonic settings: (1) NW thrusting of the metamorphic series over the sedimentary cover of the NCB (Cui et al. 1983), (2) successive NW-SEdirected compressional and extensional events related to the Triassic Indosinian orogeny (Xu et al. 1991; Chen et al. 1999), (3) formation of a Late Triassic MCC as the consequence of magmatic upwelling induced by the subduction of the Pacific plate (Yang et al. 1996), (4) N-S shortening during Late Triassic to Early Jurassic time (Xu et al. 1994) or N-S shortening between the Late Permian and the Late Jurassic due to indentation during subduction between the NCB and the SCB in the Shandong area (Yin and Nie 1993), and (5) Cretaceous extensional tectonics responsible for an asymmetric MCC of Cordilleran style with a folded Cretaceous detachment fault (Yin and Nie 1996; Liu et al. 2005). However, few of these models have taken into account the polyphase deformation and the related kinematics. Structural analysis of details is rare, and time constraints are also rare and have not been replaced in the general framework of the regional extension in eastern China.

\section{Bulk Architecture of the South Liaodong Peninsula Massif}

The bulk structures of the south Liaodong Peninsula massif are dominated by an ENE-WSW-trending antiform that has recorded a polyphase evolution, including a synmetamorphic stage (figs. 2, 3). The heterogeneously deformed gneissic migmatites form the core of the antiform. In the central part, they are weakly foliated, while in the margins, they are strongly foliated (figs. 2, 3). The boundary between the underlying migmatites and the overlying weakly metamorphosed Neoproterozoic rocks is a several-hectometers- to 2-km-thick shear zone, which was called the Jinzhou detachment fault or the Liaonan detachment fault by Yin and Nie (1996) and Liu et al. (2005), respectively. The sedimentary bedding is preserved in Neoproterozoic to Mesozoic rocks, slates, quartzites, limestones, and phyllites. These sedimentary strata are deformed by northward- or westward-verging folds (fig. 2 ; fig. $3 A, 3 B$; fig. 4). In contrast, the reference surface in the gneiss is the metamorphic foliation. In spite of local structural disturbances by the Cretaceous intrusions or late faulting, the systematic measurement of the planar structures (bedding, slaty cleavage, and foliation) shows that ENE-WSW planar structures progressively turn NW-SE at the southwestern margin and E-W in the northern part of the massif (figs. 2, 4).

\section{Structural Analysis of Polyphase Deformation in the Jinzhou Area}


Our structural analysis allows recognizing at least four successive events (referred to as pre-D1 andD1-D3) that can be distinguished on the basis of the geometry, kinematics, and structural styles of the relevant macro-, meso-, and microstructures. The separation into several distinct stages is made in order to clarify the different structures, but obviously, the D1-D3 events correspond to the same dynamics, namely, extensional tectonics, that prevailed during the formation of the south Liaodong Peninsula MCC. In this section, the deformation relevant for each event in the migmatitic basement, in the Mesozoic plutons, and in the sedimentary cover will be described successively.

\section{The Main Deformation Event (D1).}

The heterogeneous deformation was well indicated by different lithotectonic units. The regional domed foliation exhibits a conspicuous mineral and stretching lineation with a dominantly NW-SE trend (figs. 4, 5). Mylonites are well developed in the migmatite, which forms the central part of the massif, the sedimentary cover, and the Mesozoic granites (figs. 5-7).

D1 Deformation in the Migmatite. The centralpart of the south Liaodong Peninsula massif is occupied by migmatites and migmatitic gneisses. Schlieren structures, contorted leucosomes, and blasts and mafic blocks suggest a partial melting origin of the migmatites. Along the western and southeastern boundaries of the dome, migmatites exhibit a well-marked gneissic fabric, progressively turning into mylonites or even ultramylonites when moving to the detachment fault. Under the microscope, quartz grains of mylonitic migmatite are intensely deformed by crystal-plastic mechanisms. For example, elongated quartz aggregates exhibit dynamic recrystallization microstructures such as core and mantle structure or serrated newly formed grains. Conversely, high-strength minerals such as hornblende (mostly hastingsite) and K-feldspar are boudinaged and do not exhibit plastic deformation.

Though the foliation trend turns around the dome, showing diverse dip directions, the mineral and stretching lineation is consistently oriented along a NW-SE trend (fig. 4). Classical shear-sense criteria document top-to-the-northwest shearing all over the dome. Common kinematic indicators are $\mathrm{j}$ - or d-type porphyroclast systems in the mylonitic migmatites (fig. $5 A, 5 B$ ), sigmoidal shapes of mafic restites in sheared migmatites (fig. 5C), and shear bands in amphibolites (fig. 5D). Quartz, biotite, tremolite, and chlorite, which were produced by retrogression of Ca-rich amphibole, can be observed in the pressure shadows around feldspar, amphibole, and epidote clasts (fig. $6 A, 6 B, 6 D$ ). The lattice preferred orientation (LPO) of quartz provides useful information on the deformation conditions. Polished rock slices cut perpendicular to the foliation and parallel to the stretching lineation (i.e., in the $X Z$ section of the finite strain ellipsoid) of mylonites that were investigated by xray texture goniometry. In the following, only the diagrams related to the! $101^{-}$41axis, which lies at 17 to the !c1 axis, are presented. The five analyzed samples taken in the northwestern (LN 78, LN 116), central (LN 123), and southeastern parts of the massif (LN 60, LN 92) exhibit a well-marked preferred orientation of the !101 41 axes. The $! 101^{-} 41$ axes suggest a girdle pattern oblique to the foliation pole (fig. 7 ). The poorly defined girdle in sample LN 116 is due to the fact that the sample is not exactly cut in the $X Z$ section. The! $101^{-} 41$ asymmetry corroborates the top-to-the-northwest kinematics inferred from macroscopic and microscopic shear criteria (fig. 7). Although a complete orientation distribution function is not available, such an LPO pattern suggests that basal !a1 and prismatic !a1 are the dominant slip systems. Their 
activation under medium temperature or high strain rates (ca. $350^{\circ}-400^{\circ} \mathrm{C}$; Law 1990) is consistent with observed metamorphic conditions.

augen gneiss restites with K-feldspar porphyro D1 Deformation in the Mesozoic Granitoids. Mesozoic granites occupy almost one-third of the surface of the massif (fig. 2). To the south of Pulandian City, near the mylonitic zone (ductile detachment fault in fig. 2), Late Jurassic granodiorites experienced a postsolidus synmetamorphic deformation. The regional foliation exhibits a NW-SEtrending mineral and stretching lineation (fig. 2). Green biotite, epidote, amphibole, allanite, plagioclase, oligoclase (An15-20), muscovite, chlorite, and sericite mineral assemblages substantiate epidoteamphibolite to greenschist facies metamorphic conditions during deformation (Guo et al. 1996; Chen et al. 1999). A top-to-the-northwest sense of shear is indicated by asymmetric quartz or biotite pressure shadows around K-feldspar clasts, by jtype porphyroclasts systems, and by shear bands along which magmatic feldspar and amphibole are broken (figs. $5 E, 6 C$ ). The same deformation structures and kinematics can be observed in granodiorites located in the southeastern part of the dome (fig. 5F). Planar (including S-C fabrics) and linear fabrics are less developed in the Cretaceous monzogranite than in the Jurassic granodiorite, and D1-related shear sense criteria are more difficult to observe. LPO of quartz!101 ${ }^{-} 41$ axis has also been measured by texture goniometry for Jurassic and Cretaceous granitoids. Sample LN 83 corresponds to a mylonitic granodiorite, while sample LN 98 comes from the core of a granodioritic pluton exposed in the central part of the south Liaodong Peninsula massif (fig. 7). In both samples, microscopic observations show that plastic deformation is the dominant deformation mechanism of quartz aggregates.

In these samples, the quartz!101 41 axis subfabric is similar to that obtained for the foliated migmatites. The girdle asymmetry is better defined for sample LN 83 than for sample LN 98. The asymmetric pattern of sample LN 83 presents some similarities with the diagrams obtained for the foliated migmatitic host rocks. In sample LN 98, the large scattering does not allow us to infer any kinematic conclusion. As stated above, the Cretaceous monzogranites are weakly deformed. Macroscopically, their foliation is defined by a rough arrangement of biotite, and the mineral lineation is outlined by the preferred orientation of feldspar megacrysts and more rarely by the long axes of biotite platelets. Generally, a true stretching (i.e., elongated quartz grains or boudinaged plagioclase or amphibole) of the magmatic minerals along lineation is absent or weak. Under the microscope, the microstructures are quite different from those observed in the mig matite or in foliated Jurassic granodiorites. Quartz grains exhibiting serrated subgrain boundaries or dynamic recrystallization are rare. Biotite cleavage is sometimes kinked, but plagioclase is never recrystallized. These microstructures likely developed in a subsolidus state. The poorly defined LPO of the! $101^{-}$4laxes in the Cretaceous monzogranite agrees with the magmatic character of the mineral fabric.

By comparison with other examples (e.g., Gapais and Barbarin 1986), we suggest that in the Cretaceous monzogranites of the western part of the dome, quartz texture and LPO developed in a subsolidus rheological state controlled by diffusional processes. Furthermore, in the Late Jurassic granodiorites, a postsolidus state controlled the quartz texture development and crystal LPO. Thus, the Early Cretaceous monzogranites appear as syntectonic plutons, like the Yinmawanshan pluton (fig. 2; Guo et al. 2004; Liu et al. 2005). In contrast, synmagmatic structures cannot be observed in the Jurassic plutons, mainly because of intense postsolidus shearing. It ensues that the tectonic setting of those plutons remains hypothetic, as discussed below. 
D1 Deformation in the Sedimentary Cover. In the sedimentary rocks exposed in the southern and southeastern parts of the dome and in the southern tip of the Liaodong Peninsula (fig. 2), metamorphism is absent or very weak. It is limited to the recrystallization of sericite or chlorite in the Neoproterozoic pelites, or muddy limestones. Bedding is often overprinted by a slaty cleavage and by a NW-SEtrending stretching lineation marked by elongated and recrystallized chlorite, sericite, or quartz grains. Along this lineation, a top-to-thenorthwest sense of shear is indicated by sericite or chlorite-bearing shear bands (fig. 6E). The bedding surface is also deformed by NE-SWtrending folds and cleavage overturned to the northwest (figs. 2, 5G). These structures were explained by a WNW-ESE (Cui et al. 1983; Xu et al. 1991) or N-S compression (Yin and Nie 1996; Yang et al. 2002; Bing andWang 2004). Near Dalian City, aWNW-ESE stretching lineation, marked by quartz and chlorite fibers, is conspicuously observed in the weakly metamorphosed Neoproterozoic sandstones, siltstones, and phyllitic limestones (fig. 2). Along this lineation, cataclasite and ductile shear bands indicate a top-to-the-west-northwest sense of shear (figs. $5 \mathrm{H}, 6 \mathrm{~F}$ ). Because this deformation has the same geometric and kinematic features of those described in the sedimentary cover of the southeastern part of the dome (fig. 2), it can be ascribed to the D1 deformation. Thus, the main deformation (D1) is recorded in the sedimentary cover as well as in the already metamorphosed basement rocks.

The D1-related penetrative fabrics have not been observed in the western and northwestern parts of the sedimentary cover. Regionally, the D1 deformation structures are observed in every lithotectonic unit of the south Liaodong Peninsula massif. To the western side of the dome, the top-to-the-northwest kinematics are in agreement with a normal fault displacement: the sedimentary cover is moving downward to the west, which is downward. Conversely, along the southeastern margin of the dome, top-to-the-northwest shearing sense criteria observed in the southeastward-dipping foliation of orthogneiss, gneissic migmatite, and mylonitic migmatite could suggest thrusting. However, the retrogressive metamorphism and the tectonics that place Neoproterozoic or Paleozoic rocks above Paleoproterozoic migmatites do not support crustal thickening but rather thinning. In agreement with Yin and Nie (1996) and Liu et al. (2005), we consider that this apparent thrusting geometry results from arching of the foliation due to doming. A similar feature is commonly described in other MCCs (Spencer 1984; Lister and Davis 1989; Wernicke 1992; Davis et al. 2002).

Late Doming Deformation (D2). In the dome core, shear bands and west- or northwest-verging folds that deform the D1 foliation are attributed to a D2 event (fig. 3). In the sedimentary cover, D2 is characterized by different structures that will depend on the lithology. Limestones, pelites, and quartzites are deformed by NE-SWtrending folds associated with a subhorizontal or northwest-dipping axial planar cleavage. Bed-to-bed flexural slip characterized by dip-slip striation indicates normal motion in the pelitic rocks of the western flank of the south Liaodong Peninsula massif (fig. 5l, 5J). The D2 recumbent folds are compatible with a westnorthwestward displacement of the Neoproterozoic-Paleozoic sequence above the metamorphic rocks. At the scale of the whole massif, these northwest-verging D2 folds observed in the metamorphic core and in the sedimentary cover are interpreted as the later stage of the same tectonic event that is also responsible for D1 deformation. 
The flat-lying attitude of the axial planes is in agreement with a vertical shortening. Thus, the transition from D1 to D2 likely corresponds to the exhumation of the deep levels, with a progressive tilting and arching of the detachment fault. The D2 folds can be seen as gravity-driven drag folds because of the collapse of the tilted series once they have reached the critical dip that allows layer-to layer sliding. A similar evolution is also recognized in many metamorphic domes, such as, for instance, those described in SE China (Faure et al. 1996; Lin et al. 2000).

\section{Brittle Extension Faulting and Half-Graben Formation}

(D3). Another significant deformation in the study area is the high-angle brittle faulting observed to the southeast of Wafangdian or the west of Zhuanghe (figs. 2, 3C). Along the western boundary of the metamorphic complex, a brittle deformation overprints the D1 mylonites and gneisses. The west-dipping fault planes bear striations trending about $90^{\circ}$. Tension gashes, Riedel fractures, and offset markers indicate normal faulting. These normal faults represent the eastern boundary of the Wafangdian continental basin. On the western side of the basin, the red beds unconformably overlie the metamorphic and Neoproterozoic rocks. Inside the asymmetric basin, a progressive increase of the proportion of coarse deposits (i.e., red sandstone and conglomerate) is observed when approaching the fault. The sedimentological features and the tilt of the beds toward the fault suggest that normal faulting was coeval with the sedimentary infill of the halfgraben basin. Previous magnetostratigraphic work carried out to the north of the study area indicates that the age of the continental red sandstones is between 118 and $83 \mathrm{Ma}$ (Cretaceous Long Normal Superchron; Lin et al. 2003). Moreover, similar halfgraben basins are exposed in the northern and eastern parts of the south Liaodong Peninsula massif, demonstrating that the D3 brittle normal faulting belongs to the same extensional tectonics as the ductile deformation responsible for the exhumation of the metamorphic complex of the south Liaodong Peninsula massif. In summary, the D3 brittle normal faulting deforms theD1 foliation folded during D2. These D1 to D3 events represent the same extensional tectonics; however, on the basis of stratigraphy and geochronology, the brittle D3 one appears slightly younger than the ductile ones.

Evidence for a Pre-D1 Deformation. To the west of the south Liaodong Peninsula massif, field evidence indicates that a N-S shortening event occurred before the above-described D1 deformation. Northwest of Jinzhou, north-verging recumbent folds with E-W- to WNW-ESE-trending axes and an axial planar cleavage (fig. 8B$8 D)$ are recognized. Flat-lying shear zones with top-to-the-north shear senses can also be observed in the Neoproterozoic to Late Paleozoic series (figs. 2, 4, 8A). The fold axes are tilted westward by the detachment fault. Moreover, because the E-W folds are nearly perpendicular to the folds related to D2, they were probably not formed during the D1 or the D2 extensional tectonics. Therefore, we consider that the structures associated with the above-described northwestward kinematics are related to a pre-D1 event.

The E-W-trending north-verging recumbent folds suggest a N-S shortening. Because of the lack of syntectonic metamorphism associated with folding, it is difficult to estimate the time of this compressional deformation. The age of this event is stratigraphically constrained by the folding of Upper Carboniferous to Permian limestone (LBGMR 1989). The continental Cretaceous red beds and exhumed metamorphic complex are not affected by these E-W folds (fig. 2). Thus, the age of 
this deformation falls between Late Paleozoic and Early Mesozoic. In agreement with earlier work, we relate this deformation to backthrusting developed during the final collision between the NCB and the SCB during the Late Triassic (Yin and Nie 1996;

Faure et al. 2003).

\section{Geochronological Constraints}

During the fieldwork, several samples were collected from the south Liaodong Peninsula massif in order to place constraints on the timing of extensional tectonics. Nine mineral samples have been dated with the laser probe 40Ar/39Ar method using a single-grain step-heating procedure, and one sample of granodiorite has been dated by the $\mathrm{U} / \mathrm{Pb}$ method on titanite. Because of space limitations, only the main results are given here (fig. 9). Titanite yields a Middle Jurassic age (ca. 160 Ma), interpreted as the pluton emplacement age. This result is in agreement with previous results (Wu et al. 2005b). The 40Ar/39Ar dating of amphibole and biotite gives ages of 124-110 Ma that are coeval with the emplacement of Middle Cretaceous monzogranite. These ages indicate a fast cooling of granodiorites and mylonites from the detachment zone. Structures observed in the footwall of the detachment as well as the magmatic fabric in the Cretaceous plutons suggest that extension was coeval with the generation of crustal melts that migrated upward as denudation was progressing.

\section{Discussion}

The South Liaodong Peninsula MCC. Previous works and our own structural and geochronological results allow the summarizing of the main tectonic features of the south Liaodong Peninsula massif (Yin and Nie 1996; Liu et al. 2005). This area appears as an asymmetric MCC with a NE-SW-trend ing antiform axis. The dome bulk architecture and its kinematic pattern are controlled by the activity of a low-angle ductile normal fault with top-to-thenorthwest shearing. Like most MCCs, the upward arcuated shape of mylonitic zones developed during the late stages of extension, in response to isostasy (Spencer 1984; Lister and Davis 1989; Wernicke 1992). Near the southeastern termination of the south Liaodong Peninsula MCC, the weakly metamorphosed sedimentary rocks in the hanging wall occur as thin rafts on top of the detachment zone bounding the massif (fig. 3A). The sedimentary cover is deformed by west- or northwest-verging folds, the overturning of which agrees with the ductile movement observed in the metamorphic rocks, below the detachment. In the footwall, mylonitic fabrics developed at the expense of a Precambrian basement. Two generations of granitoids crop out in the core of the south Liaodong Peninsula MCC, namely, Middle Jurassic granodiorites (ca. 175-160 Ma) and Early Cretaceous monzogranites (130-120 Ma). Field observations, quartz LPO, and geochronology argue for a synkinematic emplacement of the Early Cretaceous plutons. In contrast, synmagmatic structures are erased in Jurassic plutons, probably because of intense postsolidus shearing. The tectonic setting of these plutons remains hypothetical, as discussed below. As shown by the 40Ar/39Ar ages, the ductile extension is well dated at around $120 \mathrm{Ma}$. These lines of evidence allow us to propose a crustal-scale model for the formation of the south Liaodong Peninsula MCC (fig. 10). During the Middle Jurassic, the study area was the site of a widespread magmatism represented by acidic to intermediate magmatism (LBGMR 1989), the tectonic setting of which is not well known. One may argue that it resulted from the subduction of a Paleo-Pacific oceanic plate below the eastern Eurasian margin (Wu et al. 2005b). However, this 
interpretation faces a difficulty because in Jurassic times, the study area was located nearly $1000 \mathrm{~km}$ to the west of the subduction zone. Another possibility is that Jurassic plutonism was triggered by the early inception of the Mesozoic extension, spreading out all along the Eurasian margin (see "Discussion"). This last view agrees with the opening of Jurassic half-grabens of eastern China (Li et al. 1997). Therefore, in spite of the lack of direct structural constraints, we suggest that the Middle Jurassic might represent the onset of continental extension in the study area (fig. 10A). From the Late Jurassic to the Early Cretaceous, top-to-the-northwest ductile extensional shearing widely developed across northern China (Davis et al. 1996, 2001; Darby et al. 2004). At that time, the sedimentary basins widened, and in depth, the Middle Jurassic granodiorites started to be deformed under postsolidus conditions.

Other questions concern the Middle Jurassic and Early Cretaceous plutonic activities: do they belong to two distinct geodynamic events, or do they represent two separate pulses during a single long-lasting, continuous tectonic event? Indeed, in the current state of knowledge, Jurassic plutons are documented in northeastern China but are unknown in the study area (Wu et al. 2005b; fig. 9). Furthermore, the volcanic rocks that have similar petrological and geochemical characteristics with these Jurassic plutons deposited coeval with halfgraben formation, lasting from the Middle Jurassic to the Early Cretaceous (LBGMR 1989). Thus, a geodynamic continuum seems more plausible than two distinct cycles. This interpretation is in agreement with the tectonic features observed all along the eastern Eurasian margin (Li et al. 1997; Zhang and Zheng 2003).

\section{Regional Extension along the Eastern Margin of Eurasia.}

Mesozoic extensional tectonics is recognized all along the eastern margin of Eurasia, from the Okhotsk Sea to Vietnam. The origin and geodynamic context of this continental-scale tectonic event are variously interpreted: (1) west-directed subduction of a Paleo-Pacific plate during the Mesozoic causing intra-arc or back-arc extension (Watson et al. 1987; Traynor and Sladen 1995; Ren et al. 2002), (2) interaction between the Pacific backarc spreading and a radial eastward tectonic escape resulting from the Lhasa Block-West Burma-Qiangtang-Indochina collision (Schmid et al. 1999; Ratschbacher et al. 2000); (3) E-W extension coeval with N-S shortening in relation to collision along the northern and southern boundaries of the NCB (Yin and Nie 1996; Gao et al. 2002; Zhang and Sun 2002), (4) postorogenic thinning caused by gravitational collapse of a continental crust previously thickened during a collisional event (Webb et al. 1999; Zorin 1999; Graham et al. 2001; Meng et al. 2003), (5) thermal weakening due to Early Cretaceous magmatism (Darby et al. 2004), or (6) mantle plume (Deng et al. 2004; Zhao et al. 2004). Although only a few numbers of MCCs or syntectonic plutons are currently documented, all the Early Cretaceous extensional domes in eastern China are characterized by a NW-SE stretching lineation, with top-to-the-northwest or top-to-thesoutheast sense of shear (fig. 1). In eastern China, the best-studied domes are Yiwulu" shan, Yunmengshan, Hohhot, the south Liaodong Peninsula complexes in north (Davis et al. 1996, 2001, 2002; Zhang et al. 2002; Darby et al. 2004; Liu et al. 2005), and Xiaoqinling, Xiongershan, Dayunshan, North Dabieshan, and Lushan in the south (fig. 1; Zhang et al. 1997; Hacker et al. 1998; Wang and Zhang 1999; Lin et al. 2000; Mercier et al. 2007; Verge ly et al. 2007). These domes are often associated with the formation of continental half-grabens developed in detachment footwalls (fig. 1). If all these structures have the same geodynamic origin, a scale problem arises because these extensional domes are exposed all along the eastern part of Eurasia and over more 
than $1200 \mathrm{~km}$ across strike. Indeed, the distribution of eastern Asia MCCs is much wider than the width of the Basin and Range Province MCCs; it measures between 150 and $250 \mathrm{~km}$ and is distributed parallel to the Cordilleran Orogenic Belt. In eastern China, extensional structures, such as MCCs and half-grabens, do not exhibit a clear linear pattern because they sporadically crop out in a vast area (fig. 1). Neither backarc extension related to subduction of a Paleo-Pacific plate nor interaction between collision-related eastward escape and Pacific back-arc extension can account for the large extent of continental crust involved in Early Cretaceous extension (Watson et al. 1987; Traynor and Sladen 1995; Ratschbacher et al. 2000; Ren et al. 2002). Extensional basins with rift-related volcanics, plutons, and MCCs also occur in northern Mongolia and in the Trans-Baikal region (Zorin 1999; Darby et al. 2004). Several authors (Webb et al. 1999; Darby et al. 2001; Davis et al. 2001; Wang et al. 2002; Meng et al. 2003) attributed the Cretaceous extension in southern Mongolia and in the Yinshan-Yanshan fold and thrust belt to the gravitational collapse of the Mongol-Okhotsk Belt. However, the geologic evolution of this belt remains poorly known, and crustal "unthickening" along the Mongol-Okhotsk belt, located as far as $1000 \mathrm{~km}$ north of the North China MCC, seems unable to account for extension along the eastern Eurasian continental margin in Cretaceous times. Similar extensional structures have been well reported along the Qinling-Dabieshan-Sulu orogenic belt and SCB. Different from the south Liaodong Peninsula Massif, these areas have experienced very complex compression and extension events during the Late Mesozoic (Mercier et al. 2007 and references therein; Verge' ly et al. 2007). Preview workers attributed this event to the Cretaceous mantle-derived magma promoting thermal softening and gravitational extension (Faure et al. 1996), a rolling-hinge isostatic rebound during eastward tectonic escape (Schmid et al. 1999; Ratschbacher et al. 2000), or asthenospheric upwelling through a gap opened by detachment of slab and lithospheric root (Bryant et al. 2004). However, these models do not explain the similar extensional features situated to the north in the NCB. More generally, the youngest event responsible for crustal thickening took place in the Triassic, along the Qinling-Dabie Belt, but the large time span, about $100 \mathrm{Ma}$, between the Triassic thickening and the Cretaceous extension in Sulu and western Dabieshan makes this explanation unlikely. Some authors related these extensional structures to a mantle plume (Deng et al. 2004; Zhao et al. 2004). However, such an interpretation is not supported by the regional architecture of the NCB because radial extensional structures are absent. Furthermore, the high-resolution P-wave tomography indicates that the subducting Pacific slab becomes stagnant in the mantle transition zone under East China (Huang and Zhao 2006). Intraplate or plate-margin processes appear unable to explain the Cretaceous continental-scale extension. As a matter of fact, mantle lithosphere removal might account for the large continental area involved in extensional tectonics, occurring during a quite short time span in Late Mesozoic times (Lin andWang 2006). The partial loss of the lithospheric mantle would also be responsible for a significant uplift and the rise of a high plateau (Turner et al. 1996). Although such a plateau has been suggested for Mongolia and northeastern China in Cretaceous time (Yin and Nie 1996; Meng et al. 2003), its topographic effect is not well recorded in the sedimentation because the amount of terrigeneous material deposited in the Cretaceous basins does not correspond to the important eroded volume of rock associated with such an uplift (Li et al. 1997). Moreover, the paleotopographic evolution of the Cretaceous NCB remains poorly constrained. A more detailed discussion of the models of lithosphere removal is beyond the scope of this article (see Lin and Wang 2006 for further discussion). 


\section{Conclusion}

The south Liaodong Peninsula MCC provides a good example of the Cretaceous extensional tectonics experienced by the NCB. This example combines synmetamorphic ductile shearing, synkinematic plutonism, and formation of halfgrabens. Except for the pre-D1 event corresponding to an Early Mesozoic northdirected thrusting event related to the NCB-SCB collision, the Mesozoic tectonic, metamorphic, and plutonic events recorded in the study area are related to the Cretaceous continental extension recognized in eastern China. The polyphase deformation, subdivided intoD1, D2, and D3 events, is responsible for the formation of the south Liaodong Peninsula MCC. The D1 event corresponds to an Early Cretaceous northwestward ductile shear along a detachment fault, shear responsible for the exhumation of the south Liaodong Peninsula MCC. The D2 deformation is characterized by the development of gravity-driven recumbent folds affecting the Neoproterozoic to Paleozoic sedimentary cover rocks and arching of the detachment fault. The D3 deformation is restricted to brittle normal faulting that reworks the mylonitic fabric developed during D1; D3 also controls the formation of Cretaceous continental half-grabens. The south Liaodong Peninsula MCC is the easternmost extensional dome recognized in eastern China, but Cretaceous extension is widespread in eastern Asia. The NW-SE trend of the maximum stretching direction is a general feature of this continental-scale extension. However, in spite of numerous studies, the geodynamic significance of this Cretaceous extension remains unclear. Because plate-boundary or intracrustal processes cannot satisfactorily explain all the geological features of this extension, models involving lithosphere removal must be put forward. Asthenospheric convection or "erosion" of the mantle lithosphere might account for plate thinning, crustal weakening, and development of a tensional regime throughout a wide area $(11200 \mathrm{~km})$ of eastern Asia during late Mesozoic times. Nevertheless, in the current state of knowledge, additional geophysical investigations such as seismological tomography are necessary in order to reach a satisfying understanding of the geodynamic significance of the continentalscale Mesozoic extension along the eastern margin of Eurasia.

\section{ACKNOWLEDGMENTS}

Field and laboratory expenses have been supported by the National Science Foundation of China (grant 90714007). A French CNRS Intérieur de la Terre project and grants by the French-Chinese Cooperation Foundation (AFCRST-PRA T03) and the Japan Society for the Promotion of Science (JSPS02060) are also acknowledged.We are indebted to $\mathrm{O}$. Fabbri for careful review, constructive criticism, and helpful suggestions; he is acknowledged for review of an early draft of the manuscript.

\section{REFERENCES}

Allen, M. B.; Macdonald, D. I.; Zhao, X.; Vincent, S.; and Brouet-Menzies, C. 1997. Early Cenozoic two-phase extension and late Cenozoic thermal subsidence and inversion of the Bohai Basin, northern China. Mar. Petrol. Geol. 14:951-972.

Bing, Z., and Wang, Z. 2004. Indosinian orogeny in the eastern margin of North China platform: tectonic deformation in Dalian area. Acta Geosci. Sin. 25:555-560 (in Chinese with English abstract). 
Bryant, B.; Ayers, J.; Gao, S.; Miller, C.; and Zhang, H. 2004. Geochemical, age, and isotopic constraints on the location of the Sino-Korean/Yangtze Suture and evolution of the Northern Dabie Complex, east central China. GSA Bull. 116:698-717, doi:10.1130/ B25302.1.

Chen, R.; Li, X.; Yang, Y.; Zhan, L.; Shan, X.; and Zhang, F. 1999. Bedding decollement structure of the early Indosinian orogenic cycle in the south of Liaodong Peninsula. Liaoning Geol. 16:161-169 (in Chinese with English abstract).

Cui, K.; Pang, Q.; and Xu, Y. 1983. Ductile thrusting feature at the south of Liaoning Province. Liaoning Geol. Bull. 2:45-58 (in Chinese with English abstract).

Darby, B. J.; Davis, G. A.; Zhang, X.; Wu, F.; Wilde, S.; and Yang J. 2004. The newly discoveredWaziyu metamorphic core complex, Yiwulushan, western Liaoning Province, northwest China. Earth Sci. Front. 11:145-155.

Darby, B. J.; Davis, G. A.; and Zheng, Y. 2001. Structural evolution of the southwestern Daqingshan, Yinshan belt, Inner Mongolia, China. In Hendrix, M. S., and Davis, G. A., eds. Paleozoic and Mesozoic tectonic evolution of central and eastern Asia: from continental assembly to intracontinental deformation. Geol. Soc. Am. Mem. 194:199-214.

Davis, G. A.; Darby, B. J.; Zheng, Y.; and Spell, T. L. 2002. Geometric and temporal evolution of an extension detachment fault, Hohhot metamorphic core complex, Inner Mongolia, China. Geology 30:1003-1006.

Davis, G. A.; Qian, X.; Zheng, Y.; Yu, H.; Wang, C.; Mao, T. H.; Gehrels, G. E.; Muhammad, S.; and Fryxell, J. E. 1996. Mesozoic deformation and plutonism in the Yunmeng Shan: a Chinese metamorphic core complex north of Beijing, China. In Yin, A., and Harrison, T. A., eds. The tectonic evolution of Asia. New York, Cambridge University Press, p. 253-280.

Davis, G. A.; Zheng, Y.; Wang, C.; Darby, B. J.; Zhang, C.; and Gehrels, G. E. 2001. Mesozoic tectonic evolution of the Yanshan fold and thrust belt, with emphasis on Hebei and Liaoning provinces, northern China. In Hendrix, M. S., and Davis, G. A., eds. Paleozoic and Mesozoic tectonic evolution of central and eastern Asia: from continental assembly to intracontinental deformation. Geol. Soc. Am. Mem. 194:171194.

Deng, J.; Mo, X.; Zhao, H.; Wu, Z.; Luo, Z.; and Su, S. 2004. A new model for the dynamic evolution of Chinese lithosphere: continental roots-plume tectonics. EarthSci. Rev. 65:223-275.

Fan,W. M., and Menzies, M. A. 1992. Destruction of aged lower lithosphere and asthenosphere mantle beneath eastern China. Geotecton. Metal. 16:171-179.

Faure, M.; Lin, W.; Monie' , P.; and Bruguier, O. 2004. Paleoproterozoic arc magmatism and collision in Liaodong Peninsula (north-east China). Terra Nova 16:75-80. 
Faure, M.; Lin, W.; Monie' , P.; Le Breton, N.; Poussineau, S.; Panis, D.; and Deloule, E. 2003. Exhumation tectonics of the ultrahigh-pressure metamorphic rocks in the Qinling orogen in East China: new petrologicalstructural-radiometric insights from the Shandong Peninsula. Tectonics 22:1018-1039.

Faure, M.; Sun, Y.; Shu, L.; Monie' , P.; and Charvet, J. 1996. Extension tectonics within a subduction-type orogen: the case study of the Wugongshan dome (Jiangxi Province, SE China). Tectonophysics 263:77-108.

Gao, S.; Rudnick, R. L.; Carlsonet, R. W.; McDonough, W. F.; and Liu, Y. S. 2002. Re-Os evidence for replacement of ancient mantle lithosphere beneath the North China Craton. Earth Planet. Sci. Lett. 198:307-322.

Gapais, D., and Barbarin, B. 1986. Quartz fabric transition in a cooling syntectonic granite (Hermitage massif, France). Tectonophysics 125:357-370.

Graham, S. A.; Hendrix, M. S.; Johnson, C. L.; Badamgarav, D.; Badarch, G.; Amory, J.; Porter, M.; Barsbold, R.; Webb, L. E.; and Hacker, B. R. 2001. Sedimentary record and tectonic implications of Mesozoic rifting in southeast Mongolia. GSA Bull. 113:1560-1579.

Guo, C. L.; Wu, F. Y.; Yang, J. H.; Lin, J. Q.; and Sun, D. Y. 2004. The extension setting of the Early Cretaceous magmatism in eastern China: example from the Yinmawanshan pluton in southern Liaodong Peninsula. Acta Petrol. Sin. 20:11932004 (in Chinese with English abstract).

Guo, H.; Li, Y.; and Wu, G. 1996. The signs of shearing direction of the ductile shear zone: some examples from Liaoning Province. Liaoning Geol. 13:173-187 (in Chinese with English abstract).

Hacker, B. R.; Ratschbacher, L.; Webb, L.; Ireland, T.; Walker, D.; and Dong, S. 1998. U/Pb zircon ages constrain the architecture of the ultrahigh-pressure QinlingDabie orogen, China. Earth Planet. Sci. Lett. 161: 215-230.

Huang, J. L., and Zhao, D. P. 2006. High-resolution mantle tomography of China and surrounding regions. J. Geophys. Res. 111:2005JB004066.

Huang, T. K. 1945. On the major tectonic forms of China. Geol. Mem. ser. A, no. 20, p. 1-165.

Kusky, T. M., and Li, J. H. 2003. Paleoproterozoic tectonic evolution of the North China Craton. J. Asian Earth Sci. 22:383-397.

Law, R. D. 1990. Crystallographic fabrics: a selective review of their applications to research in structural geology. In Knipe, R. J., and Rutter, E. H., eds. Deformation mechanisms, rheology and tectonics. Geol. Soc. Lond. Spec. Publ. 54:335-352.

Li, S.; Lu, F.; and Lin, C. 1997. Evolution of Mesozoic and Cenozoic basins in eastern China and their geodynamic background. Wuhan, China University of Geosciences Press, p. 1-239 (in Chinese with English summary). 
LBGMR (Liaoning Bureau of Geology and Mineral Resources). 1989. Regional geology of Liaoning Province. Geol. Mem., ser. 1, no. 14, p. 1-856 (in Chinese with English summary).

Lin,W.; Chen, Y.; Faure, M.; andWang, Q. 2003. Tectonic implications of new Late Cretaceous paleomagnetic constraints from eastern Liaoning Peninsula, NE China. J. Geophys. Res. 108:2313, doi:10.1029/2002JB002169.

Lin, W.; Faure, M.; Monie' , P.; Scha“ rer, U.; Zhang, L.; and Sun, Y. 2000. Tectonics of SE China, new insights from the Lushan massif (Jiangxi Province). Tectonics 19: 852-871.

Lin, W., and Wang, Q. 2006. Late Mesozoic extensional tectonics in North China Block: response to the lithosphere removal of North China Craton? Bull. Soc. Geol. Fr. 177:287-294.

Lister, G. S., and Davis, G. A. 1989. The origin of metamorphic core complexes and detachment faults formed during Tertiary continental extension in the northern Colorado River region, U.S.A. J. Struct. Geol. 11:65-94.

Liu, J.; Davis, G.; Lin, Z.; and Wu, F. 2005. The Liaonan metamorphic core complex, southeastern Liaoning Province, North China: a likely contributor to Cretaceous rotation of eastern Liaoning, Korea and contiguous areas. Tectonophysics 407:6580.

Lu, X.; Wu, F.; Lin, J.; Sun, D.; Zhang, Y.; and Guo, C. 2004. Geochronological successions of the Early Precambrian granitic magmatism in southern Liaodong Peninsula and it constraints on tectonic evolution of the North China Craton. Chin. J. Geol. 39:123-138 (in Chinese with English abstract).

Mattauer, M.; Matte, P.; Malavieille, J.; Tapponnier, P.; Maluski, H.; Xu, Z.; Lu, Y.; and Tang, Y. 1985. Tectonics of Qinling belt: build-up and evolution of eastern Asia. Nature 317:496-500.

Meng, Q.; Hu, J.; Jin, J.; Zhang, Y.; and Xu, D. 2003. Tectonics of the late Mesozoic wide extension basin system in the China-Mongolia border region. Basin Res. 15:397-415.

Menzies, M. A.; Fan, W. M.; and Zhang, M. 1993. Palaeozoic and Cenozoic lithoprobes and the loss of $1120 \mathrm{~km}$ of Archean lithosphere, Sino-Korean craton, China. In Prichard, H. M.; Alabaster, T.; Harris, N. B. W.; and Neary, C. R., eds. Magmatic processes and plate tectonics. Geol. Soc. Lond. Spec. Publ. 76:71-81.

Mercier, J.; Hou, M.; Vergely, P.; and Wang, Y. 2007. Structural and stratigraphical constraints on the kinematics history of the southern Tan-Lu fault zone during the Mesozoic Anhui Province, China. Tectonophysics 439:33-66.

Ratschbacher, L.; Hacker, B. R.; Calvert, A.; Webb, L.; Grimmer, J. C.; McWilliams, M. O.; Ireland, T.; Dong, S.; and Hu, J. 2003. Tectonics of the Qinling (central China): 
tectonostratigraphy, geochronology, and deformation history. Tectonophysics 366:153.

Ratschbacher, L.; Hacker, B. R.; Webb, L.; McWilliams, M. O.; Ireland, T.; Dong, S.; Calvert, A.; Chateigner, D.; andWenk, H. 2000. Exhumation of ultrahigh-pressure continental crust in east central China: Cretaceous and Cenozoic unroofing and the Tan-Lu fault. J. Geophys. Res. 105:13,303-13,338.

Ren, J.; Kensaku, T.; Li, S.; and Zhang, J. 2002. Late Mesozoic and Cenozoic rifting and its dynamic setting in eastern China and adjacent areas. Tectonophysics 344:175-205.

Schmid, J. C.; Ratschbacher, L.; Hacker, B. R.; Gaitzsch, I.; and Dong, S. 1999. How did the foreland react? Yangtze foreland fold and thrust belt deformation related to exhumation of the Dabie Shan ultrahigh-pressure continental crust (eastern China). Terra Nova 11: 266-272.

S, engor, A.M. C., and Natal'in, B. A. 1996. Paleotectonics of Asia: fragments of a synthesis. In Yin, A., and Harrison, T. A., eds. The tectonic evolution of Asia. New York, Cambridge University Press, p. 486-641.

Shang, Q. 2004. Occurrences of Permian radiolarians in central and eastern Nei Mongol (Inner Mongolia) and their geological significance to the northern China orogen. Chin. Sci. Bull. 49:2613-2619.

Spencer, J. E. 1984. Role of tectonic denudation in warping and uplift of low angle normal faults. Geology 12: 95-98.

Traynor, J. J., and Sladen, C. 1995. Tectonic and stratigraphic evolution of the Mongolian People's Republic and its influence on hydrocarbon geology and potential. Mar. Petrol. Geol. 12:35-52.

Turner, S.; Arnaud, N.; Liu, J.; Rogers, N.; Hawkesworth, C.; Harris, N.; Kelley, S.; van Calsteren, P.; and Deng, W. 1996. Post-collision, shoshonitic volcanism on the Tibetan Plateau: implications for convective thinning of the lithosphere and the source of ocean island basalts. J. Petrol. 37:45-71.

Vergely, P.; Hou, M.; Wang, Y.; and Mercier, J. 2007. The kinematics of the Tan-Lu fault zone during the Mesozoic-Palaeocene and its relations with the North ChinaSouth China Block collision (Anhui Province, China). Bull. Soc. Geol. Fr. 178:353365.

Wang, P. J.; Liu, Z. J.; Wang, S. X.; and Song, W. H. 2002. 40Ar/39Ar and K/Ar dating on the volcanic rocks in the Songliao basin, NE China: constraints on stratigraphy and basin dynamics. Int. J. Earth Sci. 91:331-340.

Wang, Z., and Zhang, X. 1999. Metamorphic core complex in Xiong'ershan and the advances in prospecting. Geol. Explor. Non-ferrous Metals 8:388-392 (in Chinese with English abstract). 
Watson, M. P.; Hayward, A. B.; Parkinson, D. N.; and Zhang, Z. M. 1987. Plate tectonic history, basin development and petroleum source rock deposition onshore China. Mar. Petrol. Geol. 4:205-225.

Webb, L. E.; Graham, S. A.; Johnson, C. L.; Badarch, G.; and Hendrix, M. S. 1999. Occurrence, age, and implication of the Yagan-Onch Hayrhan metamorphic core complex, southern Mongolia. Geology 27:143-146.

Wernicke, B. 1992. Cenozoic extensional tectonics of the U.S. Cordillera. In Burchfiel, B. C.; Lipman, P.W.; and Zoback, M. L., eds. The Cordillera orogen: conterminous US (Geology of North America, Vol. G-3). Boulder, CO, Geol. Soc. Am., p. 553-581.

Wu, F.; Lin, J.;Wilde, S. A.; Zhang, X.; and Yang, J. 2005a. Nature and significance of the Early Cretaceous giant igneous event in eastern China. Earth Planet. Sci. Lett. 233:103-119.

Wu, F.; Yang, J.; Wilde, S. A.; and Zhang, X. 2005b. Geochronology, petrogenesis and tectonic implications of the Jurassic granites in the Liaodong Peninsula, NE China. Chem. Geol. 221:127-156.

Xiao, W.; Windley, B. F.; Hao, J.; and Zhai, M. 2003. Accretion leading to collision and the Permian Solonker suture, Inner Mongolia, China: termination of the Central Asian orogenic belt. Tectonics 22, doi:10.1029/2002TC001484.

Xu, Z.; Li, H.; Wang, Z.; and Li, Z. 1991. A contraction to extension in the crust of south Liaoning Peninsula. Geol. Rev. 37:193-202 (in Chinese with English abstract).

Xu, Z. Q.; Li, H.; and Guo, L. 1994. Dynamic myrmekite, dynamic melting and transfer from crustal contraction to extension: discussion on uplifting mechanism of ancient metamorphic terrane in southern Liaoning Province. In Qian, X., ed. Research on extensional tectonics. Beijing, Geological Publishing House, p. 109_ 119.

Yang, T.; Peng, Y.; Wang, Z.; Li, D.; Yang, Z.; and Wang, G. 2002. Nearly N-S compressional deformation of sedimentary cover in the Lushun-Dalian area: intraplate deformation effect of overlying plate on continental deep-subduction of the Sulu area. Geol. Bull. China 21:308-314 (in Chinese with English abstract).

Yang, Z.; Gang, J.; Han, X.; and Meng, Q. 1996. The metamorphic core complex structure in south Liaoning. Liaoning Geol. 13:241-250 (in Chinese with English abstract).

Yin, A., and Nie, S. 1993. An indentation model for the North and South China collision and the development of the Tan-Lu and normal fault systems, eastern Asia. Tectonics 12:801-813.. 1996. A Phanerozoic palinspastic reconstruction of China and its neighboring regions. In Yin, A., and Harrison, T. A., eds. The tectonic evolution of Asia. New York, Cambridge University Press, p. 442-485. 
Zhai, M.; Zhu, R.; Liu, J.; Meng, Q.; Hou, Q.; Hu, S.; Liu, W.; Li, Z.; and Zhang, H. 2004. Time range of Mesozoic tectonic regime inversion in eastern North China Block. Sci. China 47:151-159.

Zhang, H. F. 2005. Transformation of lithospheric mantle through peridotite-melt reaction: a case of Sino-Korean craton. Earth Planet. Sci. Lett. 237:768-780.

Zhang, H. F., and Sun, M. 2002. Geochemistry of Mesozoic basalts and mafic dikes in southeastern North China craton, and tectonic implication. Int. Geol. Rev. 44:370382.

Zhang, H. F., and Zheng, J. P. 2003. Geochemical characteristics and petrogenesis of Mesozoic basalts from the North China Craton: a case study in Fuxin, Liaoning Province. Chin. Sci. Bull. 48:924-930.

Zhang, J. J.; Zheng, Y.; Shi, Q.; Yu, X.; and Zhang, Q. 1997. The Xiaoqinling detachment fault and metamorphic core complex of China: structure, kinematics, strain and evolution. In Zheng, Y.; Davis, G. A.; and Yin, A., eds. Structural geology and geomechanics: proceedings of the 30th International Geological Congress. Vol. 14. Utrecht, VSP, p. 158-172.

Zhang, X.; Li, T.; and Pu, Z. 2002. 40Ar-39Ar thermochronology of two ductile shear zones from Yiwulu" shan, west Liaoning region: age constraints on the Mesozoic tectonic events. Chin. Sci. Bull. 47:1113-1118.

Zhao, Z.; Zheng, Y.; Wei, C.; and Wu, Y. 2004. Zircon isotope evidence for recycling of subducted continental crust in post-collisional granitoids from the Dabie terrane in China. Geophys. Res. Lett. 31:L22602, doi:10.1029/2004GL021061.

Zorin, Y. A. 1999. Geodynamics of the western part of the Mongolia-Okhotsk collisional belt, Trans-Baikal region (Russia) and Mongolia. Tectonophysics 306:3356. 


\section{Figures}

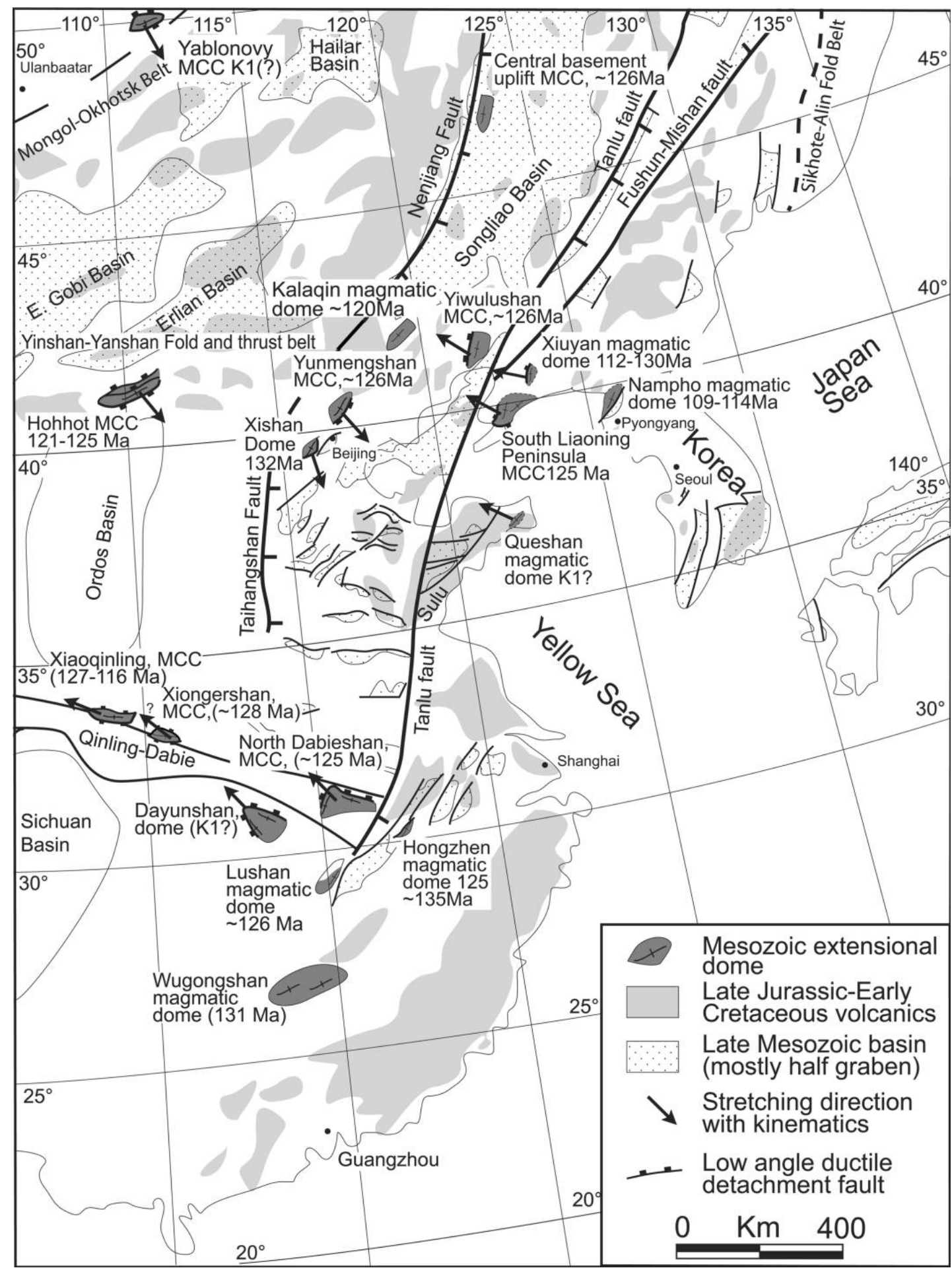

Figure 1. Distribution of geological elements related to the Late Mesozoic extension along the eastern margin of Eurasia: (dark gray) extensional domes formed around 110-145 Ma: Yunmengshan and Hohhot (Davis et al. 1996, 2002), Yablonovy (Zorin 1999), Yiwulu“ shan and Kalaqin (Zhang et al. 2002; Darby et al. 2004), North Dabieshan (Hacker et al. 1998), Lushan (Lin et al. 2000), Wugongshan (Faure et al. 1996), Dayunshan (W. Lin, unpublished manuscript), Xiaoqinling (Zhang et al. 1997), Xiongershan (Wang and Zhang 1999), and Hongzhen (Verge' ly et al. 2007); (light gray) Late Jurassic to Early Cretaceous volcanics; (dotted) Late Mesozoic continental red beds basin. (Modified from Allen et al. 1997; Ren et al. 2002; Meng et al. 2003.) 


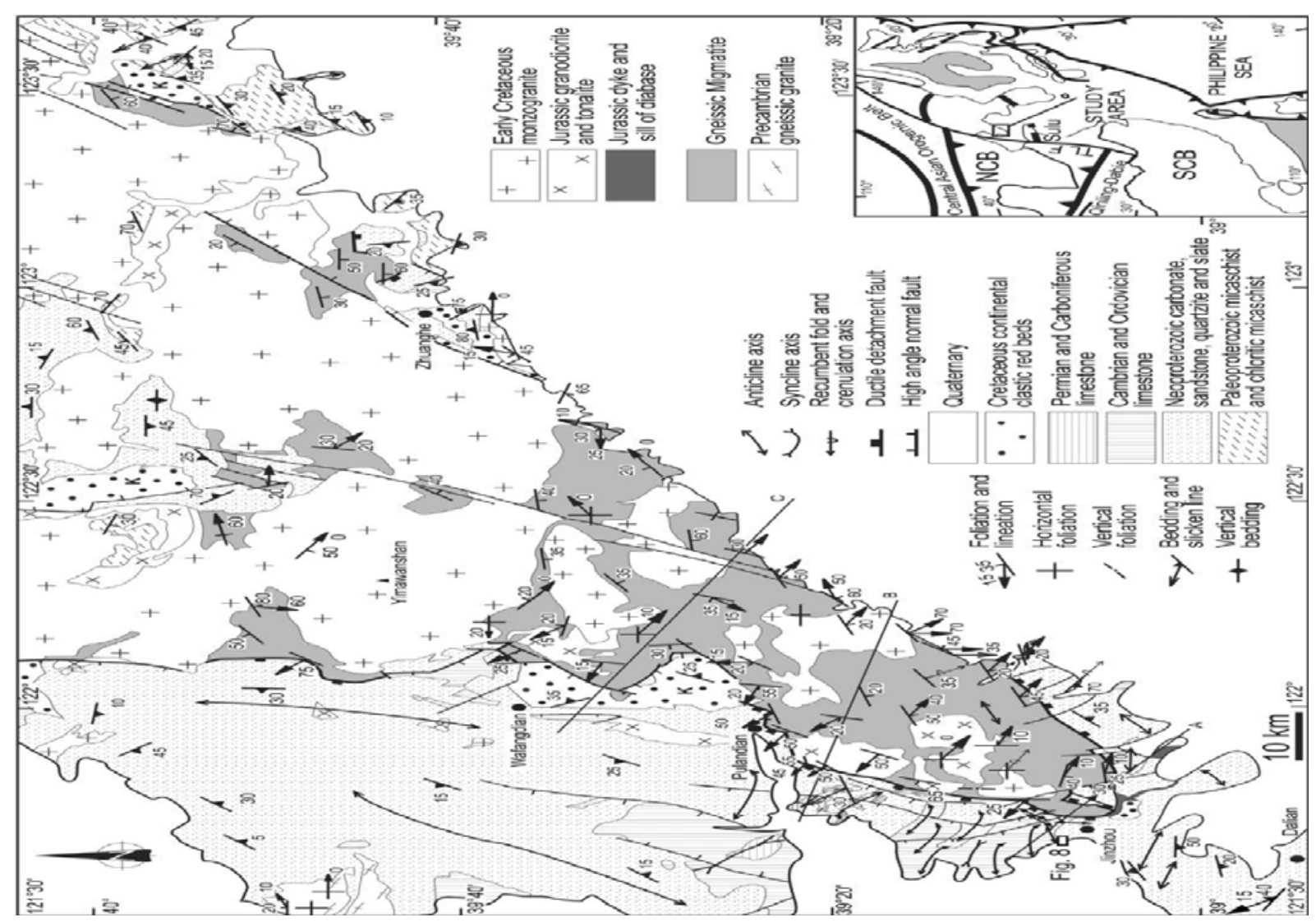

Figure 2. Structural map of the south Liaodong Peninsula massif. Inset shows the location of the massif in East Asia. 

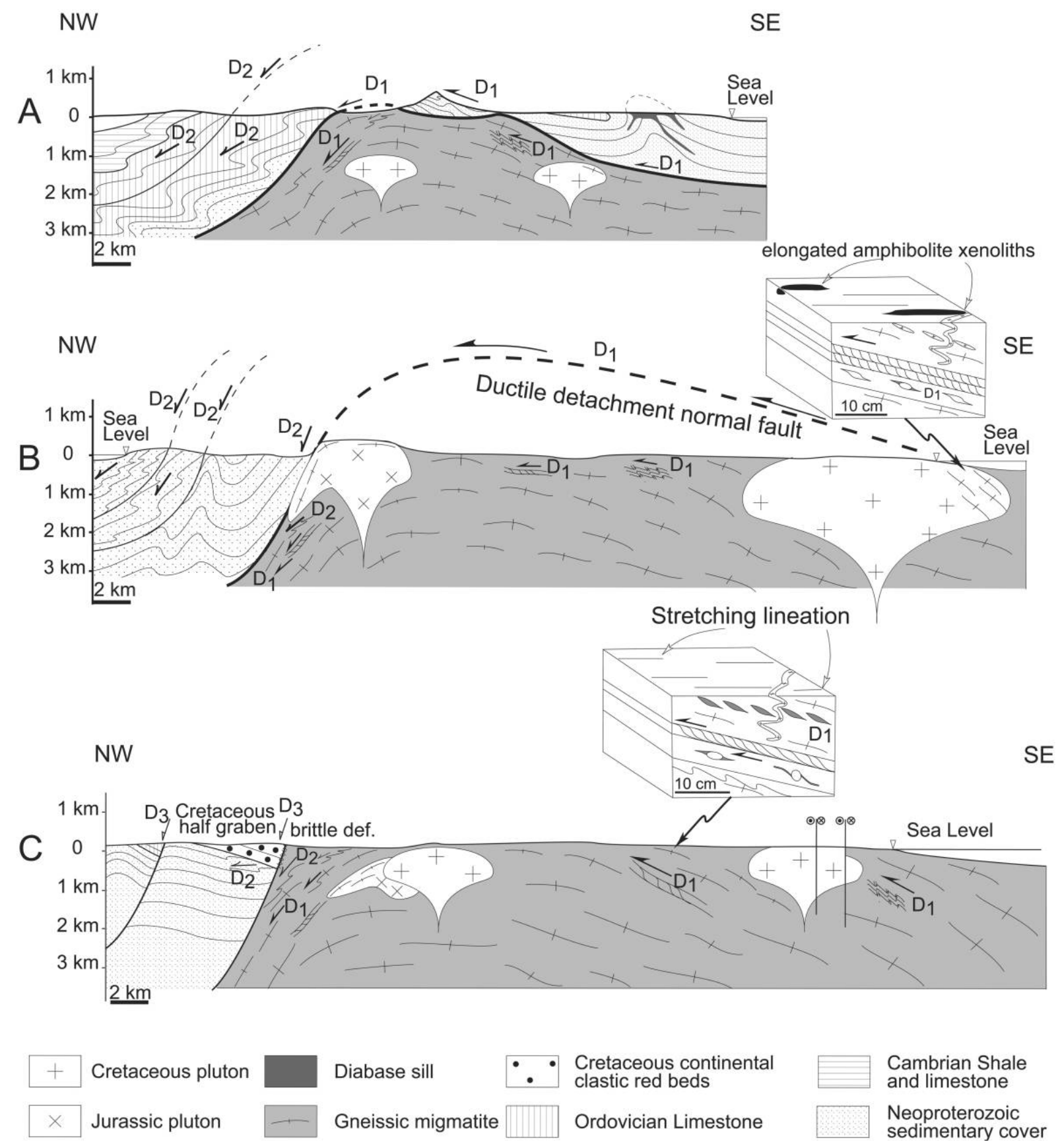

Figure 3. Cross sections through the south Liaodong Peninsula massif (location in fig. 2) drawn parallel to the direction of the main mineral and stretching lineation (the pluton roots are hypothetical). 


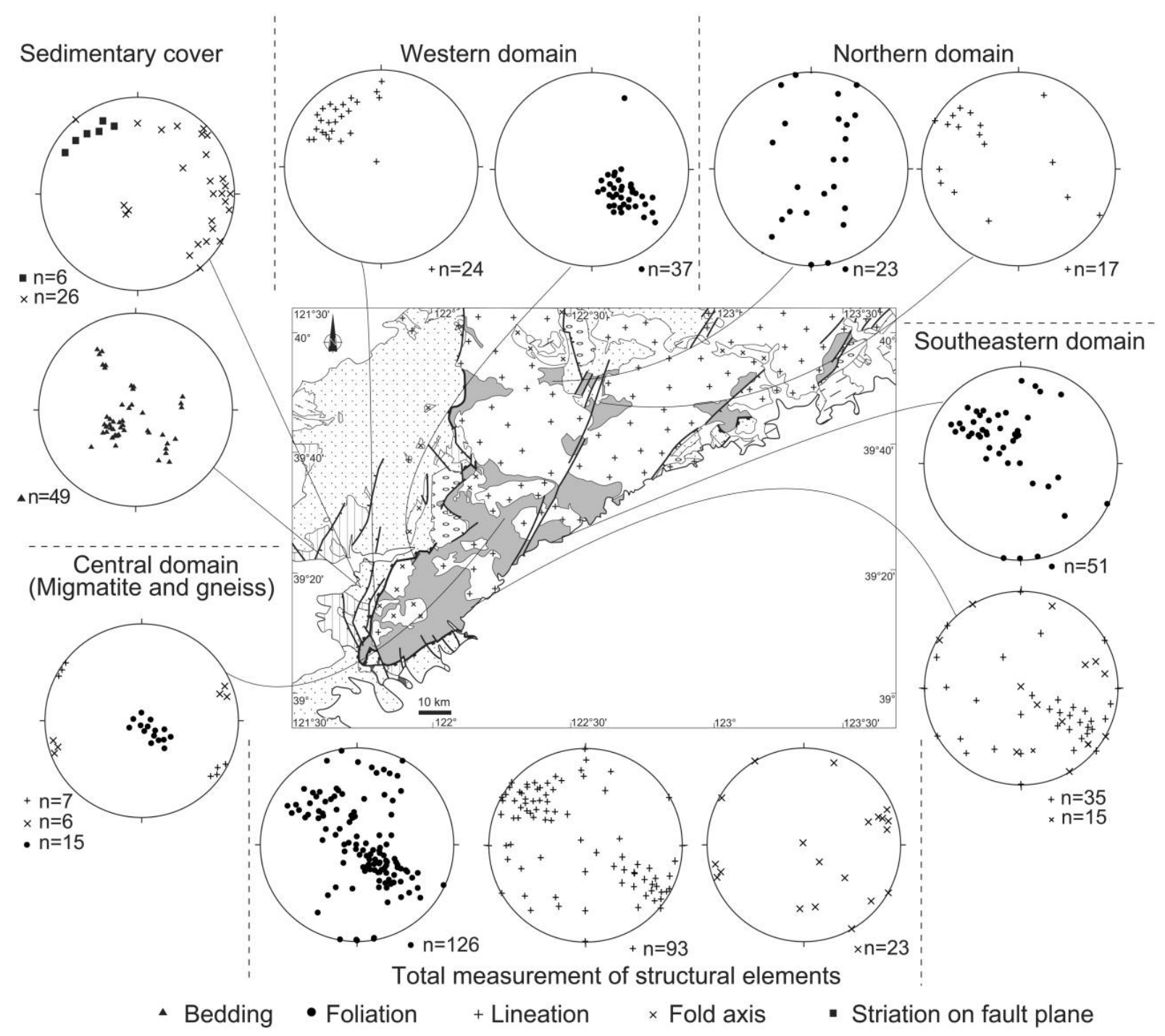

Figure 4. Structural planar and linear elements of the south Liaodong Peninsula massif: foliation, bedding, mineral and stretching lineation, and striation on fault plane. All diagrams are equiareal Schmidt net, lower-hemisphere projections. Symbols and captions in the map are the same as in figure 2 . 

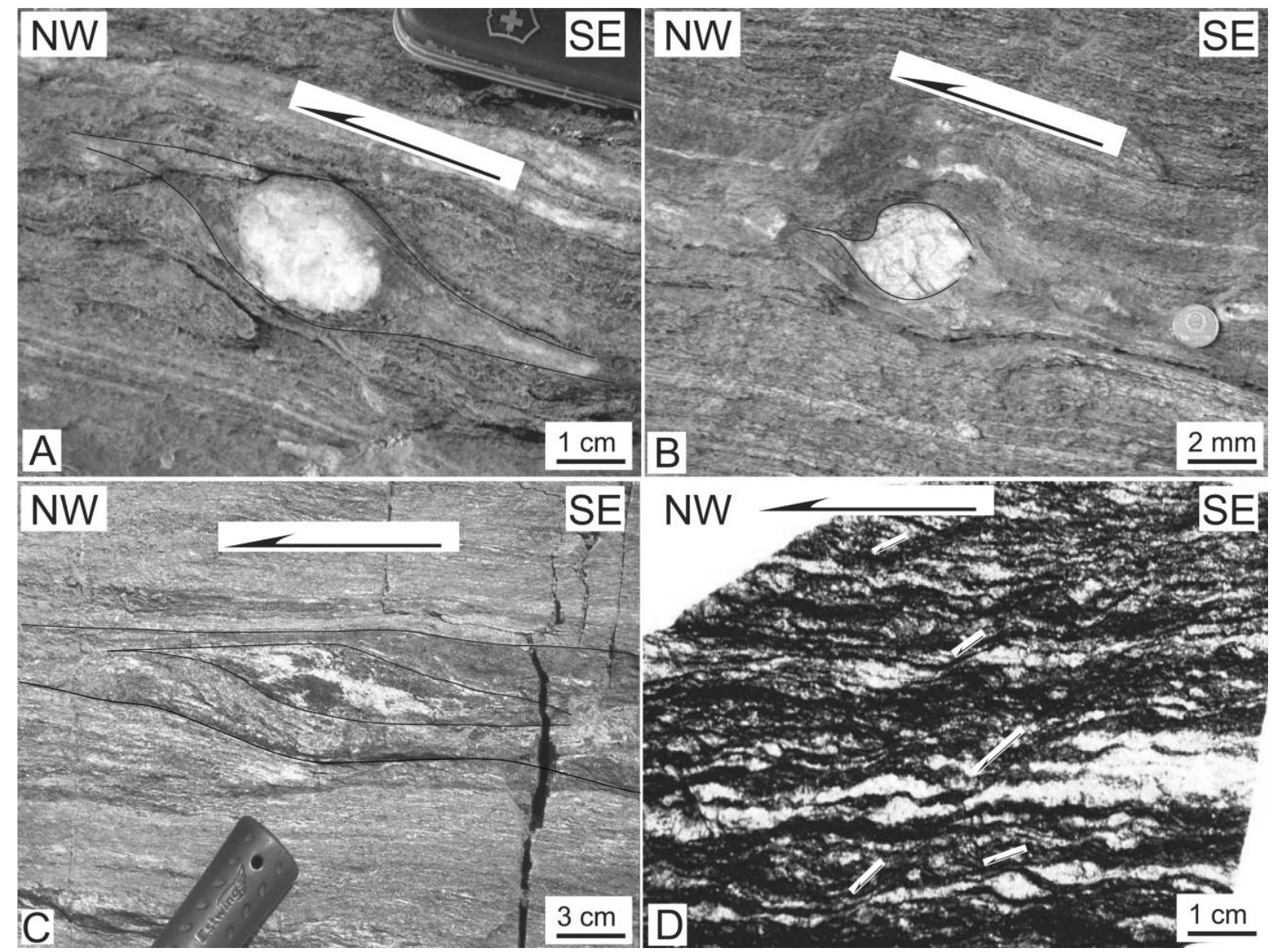

Figure 5. Field-scale photographs showing top-to-the-northwest shear sense criteria. $A$, Migmatite with $\mathrm{K}$-feldspar porphyroclast and sigmoidal quartz pressure shadow (Dongjiagou, E of Jinzhou City). $B$, d-type K-feldspar porphyroclast in migmatite (Dongjiagou, E of Jinzhou City). C, Sigmoidal mafic restite in migmatite (S of Pulandian). $D$, Shear band developed in amphibolite (SW of Pulandian City). $E$, Late Jurassic porphyritic granodiorite similar to the sample LN 83 dated by U/Pb method at ca. 160 Ma and mylonitized around $120 \mathrm{Ma}$ (SW of Pulandian City); feldspar clasts show top-to-the-northwest shear sense. $F, S-C$ fabric in the mylonitic margin of a Cretaceous monzogranitic pluton (SW of Zhuanghe City). G, Folded bedding (SO) deformed by microfolds and crenulation cleavage (S1) in Neoproterozoic interlayers of mudstone and quartzite (W of Dalian City). $H$, Cataclastic shear band in weakly metamorphosed mudstone and quartzite of Neoproterozoic age (W of Dalian City). I, Meterscale D2-related recumbent fold overturned to the west in Neoproterozoic pelitic limestone (E of Jinzhou City). J, Meter-scale decollement with normal displacement along the pelitic interlayers in Neoproterozoic quartzite related to the deformation of sedimentary cover. Note the development of low-angle and high-angle cleavage in pelitic-rich and quartz-rich lithologies, respectively (SW of Pulandian City). 


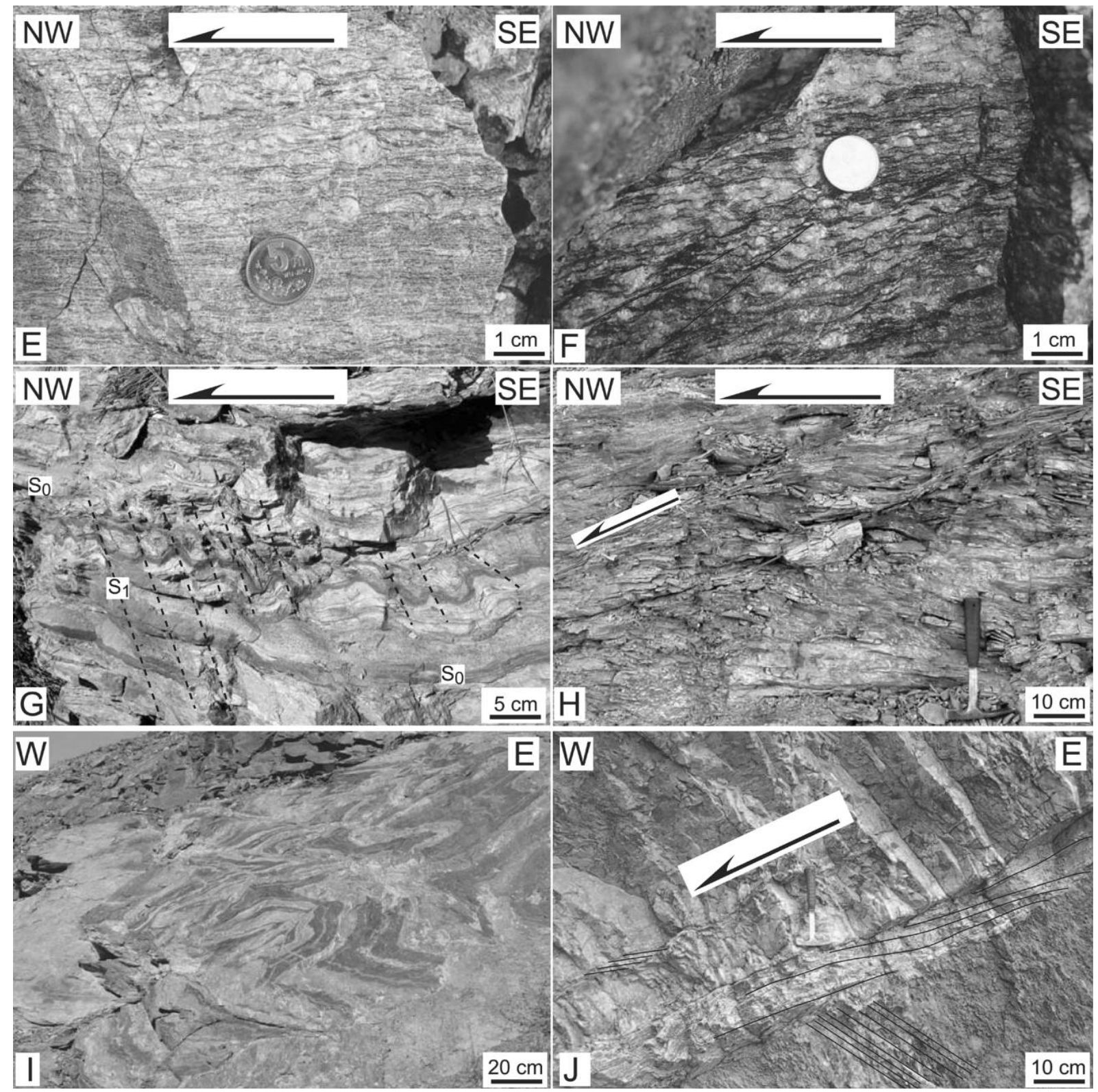

Figure 5. (Continued) 

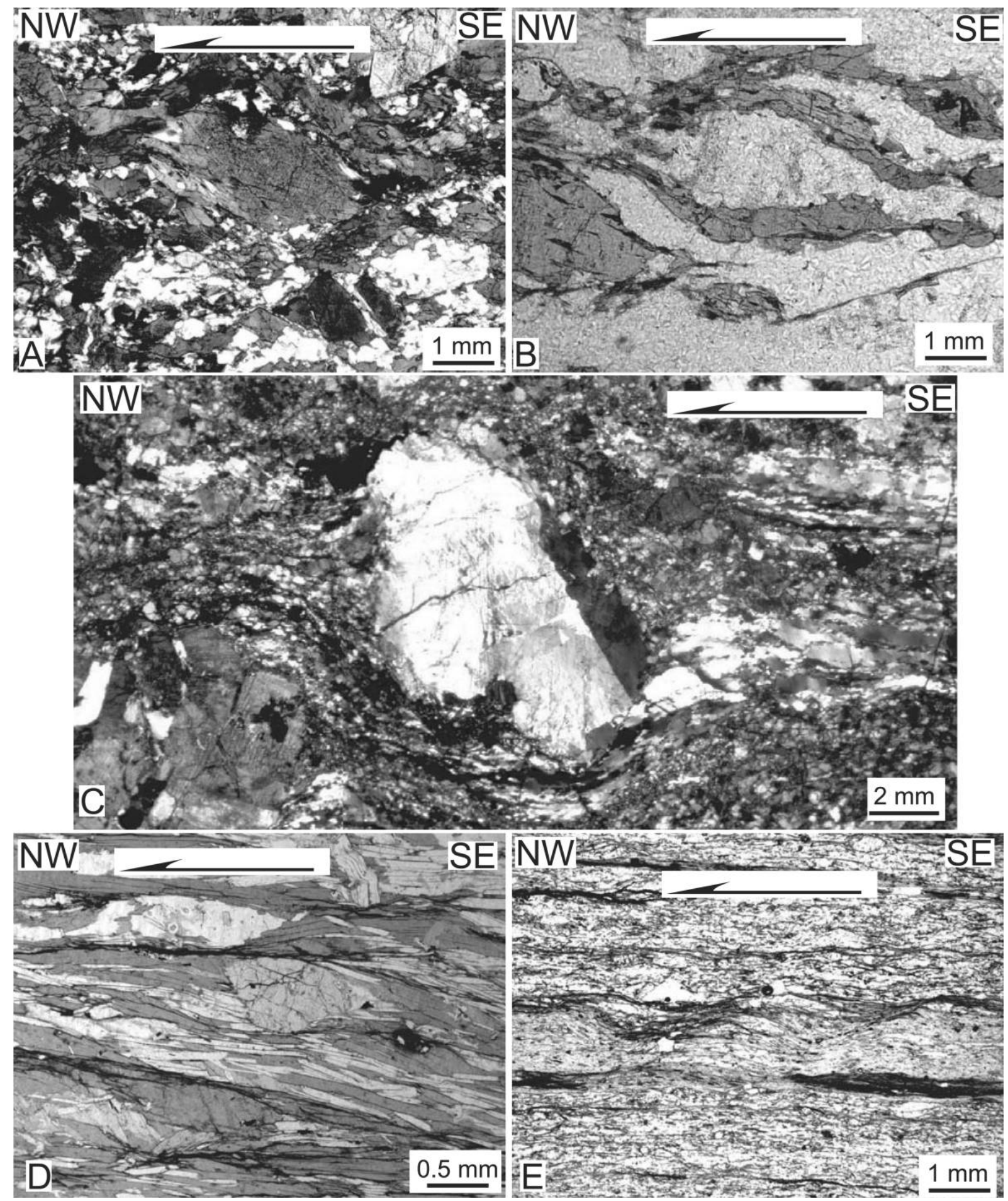

Figure 6. Photomicrographs showing top-to-the-northwest shear criteria from various lithologies: foliated migmatites, granitoids, micaschists, and sedimentary rocks. All thin sections are cut perpendicular to the foliation and parallel to the mineral and stretching lineation. $A$, j-type D1-related porphyroclast system around amphibole in amphibolite layer within migmatite (LN 111, E of Wafangdian). B, j-type porphyroclast system of K-feldspar in mylonitic granite (LN 246, SW of Pulandian). C, Top-to-the-northwest asymmetric pressure shadow around feldspar clast in mylonitic Late Jurassic granite (SE of Pulandian). In the field, the foliation dips northwestward, and the mineral and stretching lineation is downdip. $D$, Biotite around epidote in Paleoproterozoic micaschist (LN 41, $\mathrm{E}$ of Zhuanghe). $E$, Chlorite developed in shear bands in the weakly metamorphosed Neoproterozoic sedimentary cover (S of Jinzhou City). 

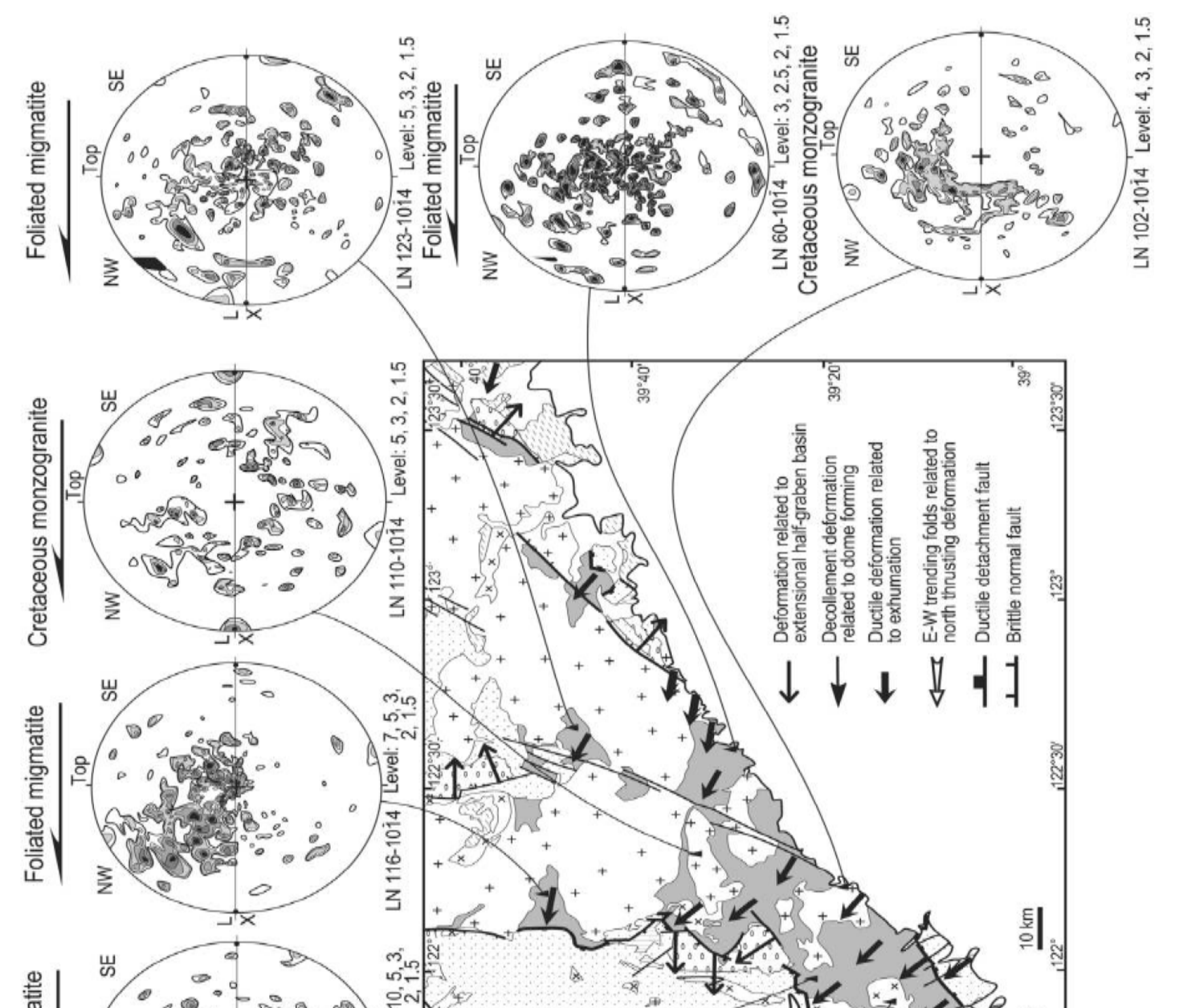

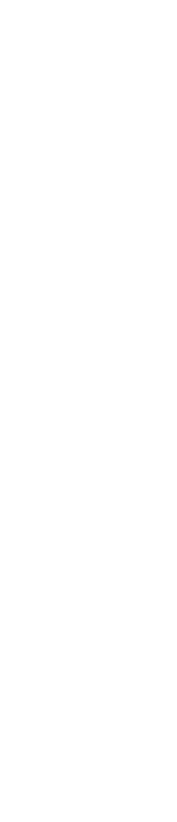

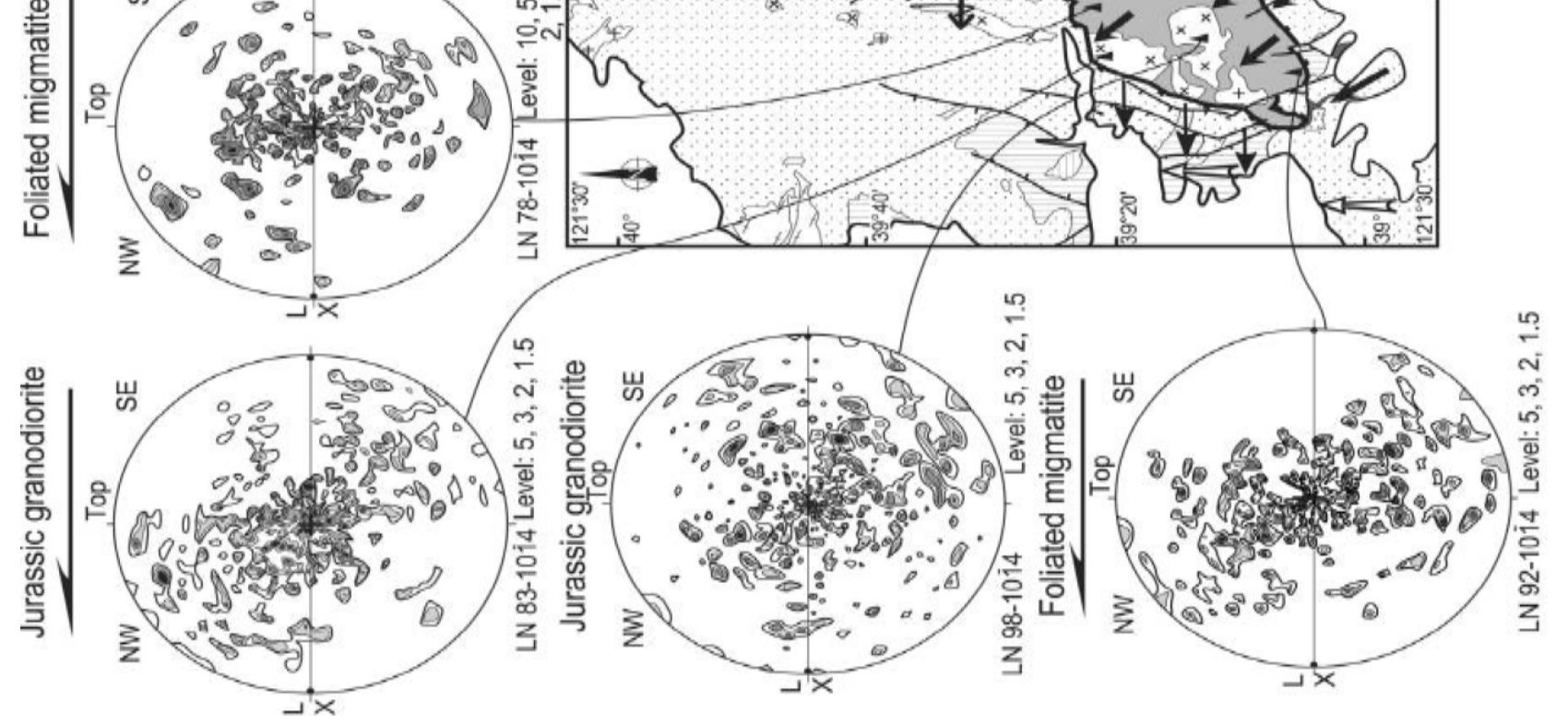


Figure 7. Kinematic map for the different tectonic events in the south Liaodong Peninsula massif and examples of quartz lattice preferred orientation obtained by texture goniometry. Symbols and captions in the map are the same as in figure 2. Arrows point to the sense of shear of the upper layer over the lower layer. Samples are foliated or mylonitic migmatite (LN 60, LN 78, LN 92, LN 116, and LN 123), mylonitic Jurassic granite (LN 83, LN 98), and foliated Cretaceous granite (LN 102, LN 110). All diagrams are lower-hemisphere Schmidt net drawn in the $\mathrm{XZ}$ section of the bulk strain ellipsoid (perpendicular to foliation and parallel to mineral and stretching lineation). Contour intervals given as multiples of random distribution are shown for each sample.
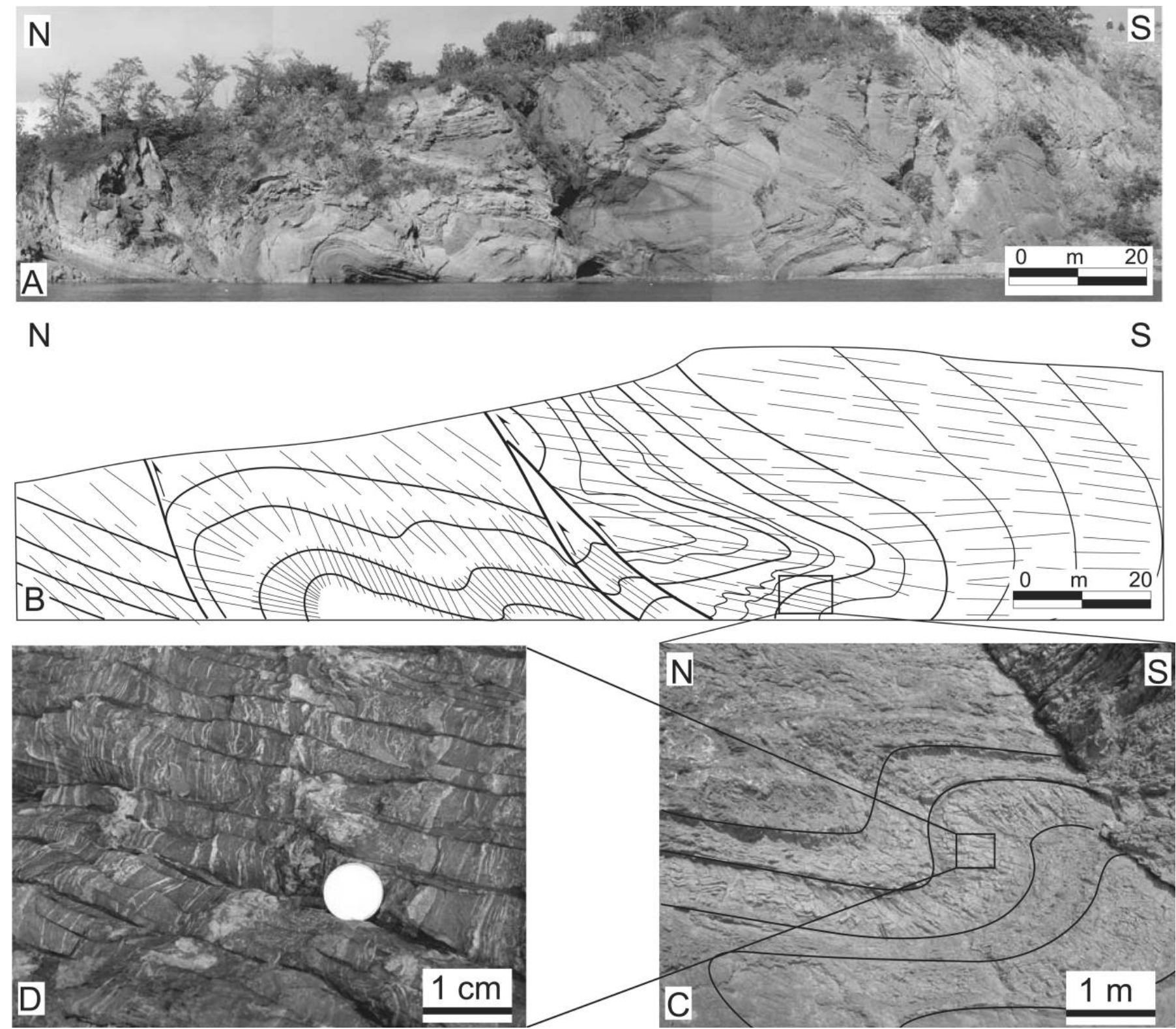

Figure 8. Evidence for a pre-D1 event. $A$, Field photograph showing north-verging recumbent folds and thrust faults

in Neoproterozoic sandstone, NW of Jinzhou City (located in fig. 2). B, Interpretative sketch of the section at the same scale. $C, D$, Detail of the axial planar cleavage at the meter and centimeter scales, respectively. 


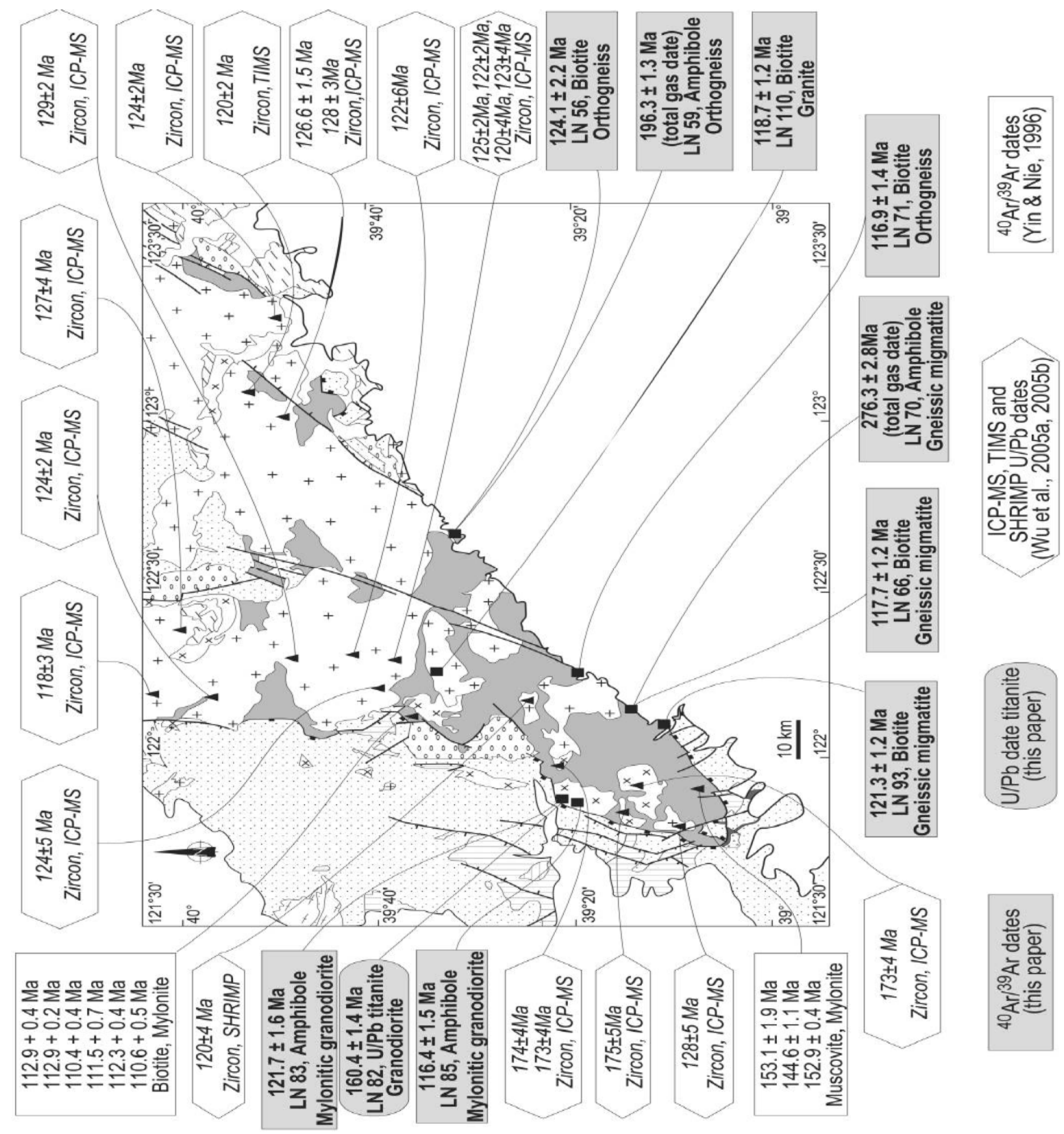

Figure 9. Structural map of the south Liaodong Peninsula massif showing the available radiometric data. Symbols and captions in the map are the same as in figure 2. 

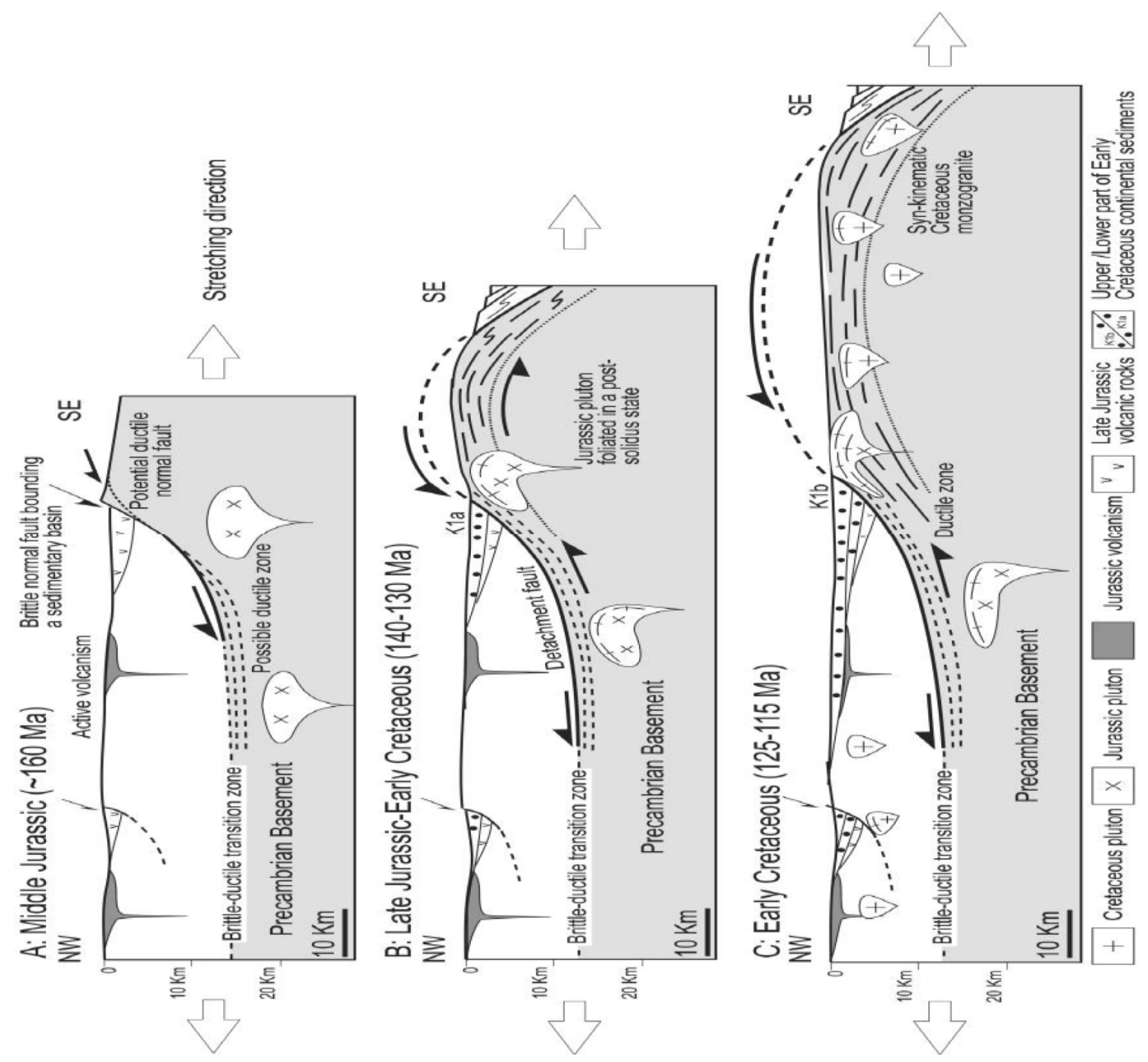

Figure 10. Schematic two-dimensional diagram showing the regional extensional tectonics, doming, and half-graben formation in the south Liaodong Peninsula massif. $A$, Jurassic extension coeval with volcanism and volcanic-sedimentary deposits in half-graben basins in the hanging wall granodioritic plutonism in the footwall. At this time, ductile shearing is not documented by our field observation. $B$, Development of a major detachment fault in Late Jurassic-Early Cretaceous times. In the hanging wall, the half-graben filled by continental terrigeneous red deposits (K1a) widens. In the footwall, the Precambrian migmatitic and metamorphic complex starts to be exhumed, and the Jurassic granodioritic plutons are foliated in a postsolidus state. C, During the Early Cretaceous, continued extension is responsible for the exhumation of the metamorphic core complex to the surface, arching of the detachment normal fault, andemplacement of syntectonic Cretaceous plutonism with subsolidus fabrics. 